\title{
H
}

1. EN 651650

Page 1 of 2 Proj. $N / A$

\begin{tabular}{|c|c|c|c|c|}
\hline $\begin{array}{l}\text { 2. ECH Category } \\
\text { (mark one) } \\
\text { Supplenental } \\
\text { Direct Revision }\end{array}$ & $\underset{[x]}{[]}$ & $\begin{array}{l}\text { 3. Originator's Name, Organization, MsIM, } \\
\text { and Telephone No. } \\
\text { MF Hackworth, WMH, 373-386l }\end{array}$ & $\begin{array}{l}\text { 4. Use Required? } \\
{[X] \text { Yes [] No }} \\
\text { WRP-99-021 }\end{array}$ & $\begin{array}{l}\text { 5. Date } \\
02 / 08 / 99\end{array}$ \\
\hline $\begin{array}{l}\text { Change ECN } \\
\text { Terporary } \\
\text { Standby }\end{array}$ & [] & $\begin{array}{l}\text { 6. Project Iitle/No./Work Order No. } \\
\text { N/A }\end{array}$ & $\begin{array}{c}\text { 7. Bldg./Sys./Fac. Mo. } \\
\text { 2336-W }\end{array}$ & $\begin{array}{l}\text { 8. Approval Desionator } \\
\text { SQ }\end{array}$ \\
\hline Cancel/Noid & [] & $\begin{array}{l}\text { 9. Docuinent Muibers Chenged by this ECK } \\
\text { (includes sheet no. and rev.) } \\
\text { HNF-SD-W026-TA-002, Rev, 1, A11 }\end{array}$ & $\begin{array}{l}\text { 10. Related ECN Ho(s). } \\
\qquad N / A\end{array}$ & $\begin{array}{l}\text { 11. Related PO Mo. } \\
\qquad N / A\end{array}$ \\
\hline
\end{tabular}

12a. Modification Work

[] Yes (fill out Blk. 12b)

12b. Work Package No. \begin{tabular}{l} 
12c. Modification Work Complete \\
N/A \\
\hline Design Authority/Cog. Engineer \\
Signature \& Date
\end{tabular}

12d. Restored to Original Condition (Temp. or Standby ECN only) N/A $N / A$

[X] No (WA Blks. 12b, 12c, 12d)

13a. Description of Change

13b. Design Basetine Document? [] Yes [X] No

This document is being revised in it's entirety and complies with Project Hanford Policies and Procedure HNF-PRO-331, Work Place Air Monitoring

14a. Justification (mark one)

$\begin{array}{llllllll}\text { Criteria Change } & {[X]} & \text { Design Improvement } & {[]} & \text { Environmental } & \text { [] } & \text { Facility Deactivation [] } \\ \text { As-Found } & {[]} & \text { Facilitate Const } & {[]} & \text { Const. Error/Omission } & \text { [] } & \text { Design Error/Omission [] }\end{array}$

14b. Justification Details

The annual review of this document warrants a full revision.

15. Distribution (include name, MSIN, and no. of copies)

See attached distribution sheet. 


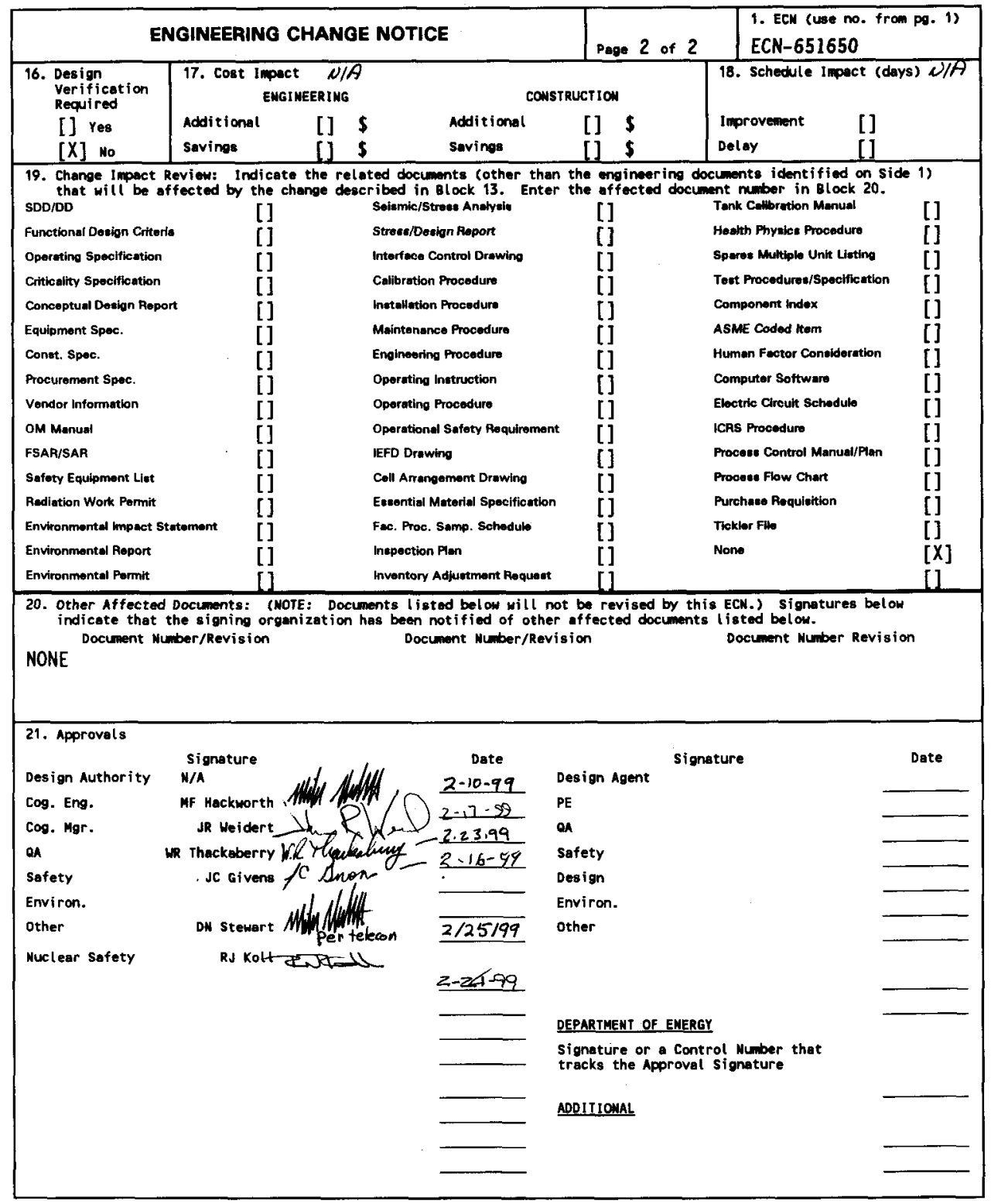




\section{TECHNICAL ASSESSMENT OF COMPLIANCE WITH WORKPLACE AIR SAMPLING REQUIREMENTS AT WRAP}

NF Hackworth

Waste Management Federal Services of Hanford, Inc, Richland, WA 99352

U.S. Department of Energy Contract DE-AC06-96RL13200

$\begin{array}{lll}\text { EDT/ECN: } & \text { ECN-651650 } & \text { UC: } 607 \\ \text { Org Code: } & 32600 & \text { Charge Code: } \\ \text { B\&R Code: } & \text { EW02J126 } & \text { Total Pages: } 43\end{array}$

Key Words: WRAP, Workplace air monitoring, WAM, HSRCM-1

Abstract: Technical assessment of compliance with workplace air sampling requirements at the Waste Receiving and Processing (WRAP) Facility, annual update.

*Versapore 3000 is a registered trademark of Gelman Sciences, Inc., Ann Arbor, MI.

*Nylon and Tefion are a registered trademarks of E.I. du Pont de Nemours \& Co., Wilmington, DE.

*Fluoropore is a trademark of Millipore Corporation, Bedford, MA.

TRADEMARK DISCLAIMER. Reference herein to any specific coniercial product, process, or service by trade name, trademark, manufacturer, or otherwise, does not necessar ily constitute or imply its endorsenent, reconnendation, or favoring by the United states Government or any agency thereof or its contractors or subcontractors.

Printed in the united states of America. To obtain copies of this document, contact: Document Control Services, P.0. Box 950, Mailstop H6-08, Richland HA 99352, Phone (509) 372-2420; Fax (509) 376-4989.

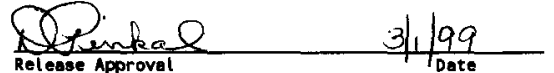

Retesse Approval

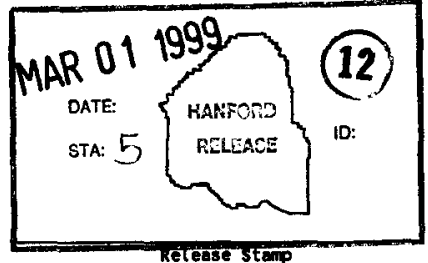

kéterses staip 


\section{RECORD OF REVISION}

(2) Title

Technical Assessment of Compliance with Workplce Air Sampling Requirements at WRAP CHANEE COWTROL RECORD

\begin{tabular}{|l|l|l|l|}
\hline \multirow{2}{*}{ (3) Revision } & \multirow{2}{*}{ (4) Description of Change - Replace, Add, and Delete Poges } & \multicolumn{2}{|c|}{ Authorized for Release } \\
\cline { 3 - 5 } & $\begin{array}{c}\text { (7) Initial Release Rev. 0, dated 9/30/9 } \\
\text { per EDT-701911 }\end{array}$ & & \\
\hline & Complete revision per ECN-641734 & \\
\hline RS 2 & Complete revision per ECN-651650 & $\begin{array}{l}\text { (5) Engr. } \\
\text { MF Hackworth }\end{array}$ \\
\hline
\end{tabular}

\begin{tabular}{|l|l|l|}
\hline & & \\
\hline &
\end{tabular}


HNF-SD-W026-TA-002 Revision 2

Page 1 of 41

SUPPORTING DOCUMENT

TECHNICAL ASSESSMENT OF COMPLIANCE WITH

WORKPLACE AIR SAMPLING REQUIREMENTS

AT THE WASTE RECEIVING AND PROCESSING

FACILITY (WRAP)

Waste Management Federal Services of Hanford, Inc.

Michael F. Hackworth 
HNF-SD-W026-TA-002

Revision 2

Page 2 of 41

CONTENTS

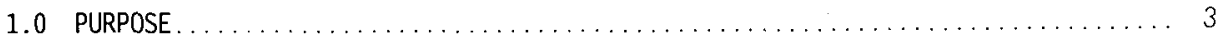

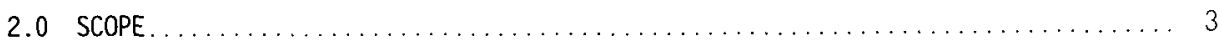

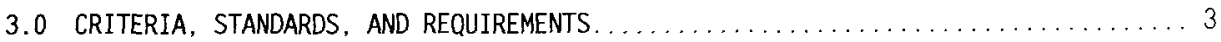

4.0 TECHNICAL BASIS FOR WORKPLACE AIR MONITORING (WAM) PROGRAM $\ldots \ldots \ldots \ldots \ldots \ldots$

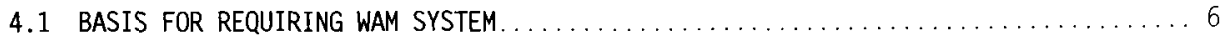

4.2 BASIS FOR DECLARING WAM NOT REQUIRED ........................ 7

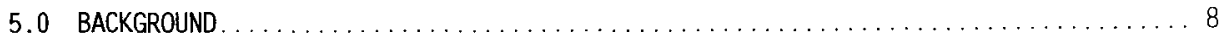

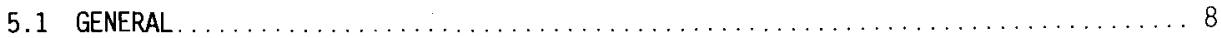

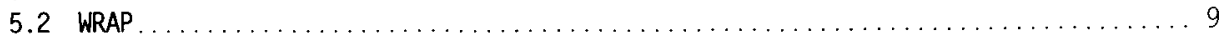

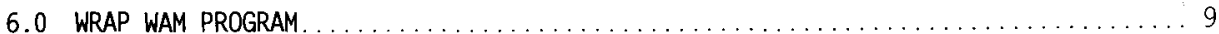

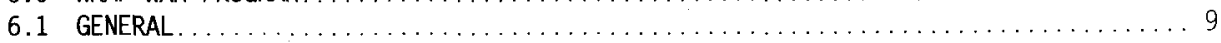

6.2 BUILDINGS/ROOMS THAT DO NOT MEET WAM CRITERIA $\ldots \ldots \ldots \ldots \ldots \ldots \ldots \ldots \ldots \ldots \ldots \ldots \ldots$

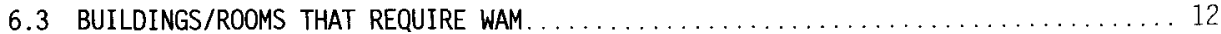

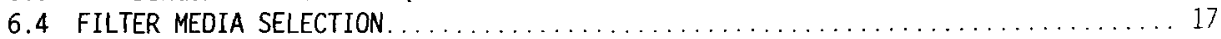

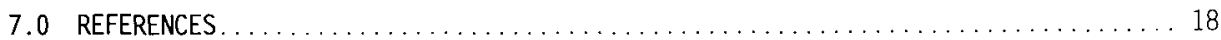

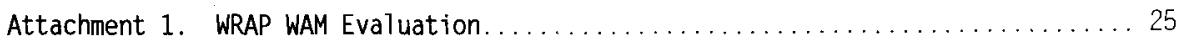


HNF-SD-W026-TA-002

Revision 2

Page 3 of 41

\subsection{PURPOSE}

The purpose of this Technical Assessment is to satisfy HSRCM-1. "Hanford Site Radiological Control Manual" Article 551.4 for a documented study of facility Workplace Air Monitoring (WAM) programs. HSRCM-1 is the primary guidance for radiological control at Waste Management Federal Services of Hanford. Inc. (WMH). The HSRCM-1 complies with Title 10. Part 835 of the Code of Federal Regulations (10CFR835). This document provides an evaluation of the compliance of the Waste Receiving and Processing facility (WRAP) WAM program to the criteria, standards, requirements, and documents compliance with the requirements where appropriate. Where necessary, it also indicates changes needed to bring specific locations into compliance.

\subsection{SCOPE}

The criteria. standards, and requirements contained in this document apply only to airborne particulate sampling in the workplace. While many of the same requirements apply to air sampling and monitoring for facility effluent streams and for the environmental ambient air sampling program. this document excludes them. The compliance appraisal in this document assumes the placement of fixed WAM equipment in facility areas that are normally or continuously occupied as part of facility operations, and such sampling systems are strongly recommended for this purpose. Air sampling for non-routine or infrequent activities are conducted as described in HNF-PRO-666. Grab Air Sampling. If potential airborne contamination is suspected, a Radiological Work Permit (RWP) will be included in the work package to specify the air sampling requirements for personnel protection. Conclusions concerning compliance to requirements and changes necessary for compliance apply only to WRAP.

\subsection{CRITERIA, STANDARDS, AND REQUIREMENTS}

The Department of Energy, through 10CFR835, requires its contractors to conduct air monitoring to detect and evaluate airborne radioactive material in the workplace. A compilation of the criteria and standards applicable to WAM programs is contained in HNF-PRO-331, Work Place Air Monitoring. A description of the criteria as follows: 
HNF-SD-W026-TA-002

Revision 2

Page 4 of 41

\section{CFR 835}

Paragraph $835.403(a)(1)$

Air sampling shall be performed in occupied areas where, under typical conditions, an individual is likely to receive an annual intake of 2 percent or more of the specified ALI values. For a given radionuclide, and lung retention class, the ALI is the product of the DAC 1isted in appendix A of this part, and the constant $2.4 \times 10^{9} \mathrm{ml} \ldots$

Paragraph 835.403 (a)(2)

Real-time air monitoring, using continuous air monitors ... shall be performed in normally occupied areas where an individual is 7ikely to be exposed to a concentration of airborne radioactivity exceeding 1 DAC as specified in appendix A of this part or where there is a need to alert potentially exposed individuals to unexpected increases in airborne radioactivity levels.

Paragraph 835.403 (a)(3)

For the airborne radioactive material that could be encountered, real-time air monitors shall have alarm capability and sufficient sensitivity to alert potentially exposed individuals that immediate action is necessary in order to minimize or terminate inhalation exposures.

Paragraph 835.403 (b)

Monitoring of radiation in the workplace shall be performed using stationary (area) or portable radiation instruments, or a combination thereof..."

\section{$\underline{\text { HSRCM-1 }}$}

Article 551.4

The Radiological Control Organization sha11 perform and document a review of the adequacy of sampling and monitoring systems as part of any facility or operational changes affecting radiological control. In the absence of such changes, a review should be conducted annually. 
HNF-SD-W026-TA-002

Revision 2

Page 5 of 41

$\underline{\text { HSRCM-1 }}$

Article 555.1

In addition to the requirements of Article 551, air monitoring equipment should be used in situations where airborne radioactivity levels can fluctuate and early detection of airborne radioactivity could prevent or minimize inhalation of radioactivity by personnel. Selection of air monitoring equipment should be based on the specific job being monitored. Air monitoring equipment includes portable and fixed air sampling equipment and continuous air monitors.

Article 555.2

Air sampling equipment shall be used in occupied areas where. under normal operating conditions, a person is likely to receive an annual intake of 2 percent or more of the specified Annual Limit of Intake (AL.I) values...

Article 555.3

Continuous air monitoring equipment shall be installed in occupied areas where a person without respiratory protection is likely to be exposed to a concentration of radioactivity in air exceeding 1 DAC, or where there is a need to alert potentially exposed workers to unexpected increases in the airborne radioactivity levels. A person exposed continuously to a concentration of radioactivity in air of 1 DAC for 1 work week would generally receive a committed effective dose equivalent of approximately $100 \mathrm{mrem}$.

Article 555.4

Air sampling equipment should be positioned to measure air concentration to which persons are exposed. If this cannot be achieved, a program of personal breathing-zone air sampling should be initiated. 
HNF-SD-W026-TA-002

Revision 2

Page 6 of 41

$\underline{\mathrm{HSRCM}-1}$

Article 555.5

Air monitoring equipment shall be routinely calibrated and maintained at a frequency of at least once per year. Continuous air monitors should be capable of measuring 1 DAC when averaged over 8 hours ( 8 DAC-hours) under laboratory conditions.

Article 555.6

Continuous air monitoring equipment required by Article 555.3 shall have alarm capability and sufficient sensitivity to alert personnel that immediate action is necessary in order to minimize or terminate inhalation exposures.

\subsection{TECHNICAL BASIS FOR REQUIRING WORKPLACE AIR MONITORING}

\subsection{BASIS FOR REQUIRING A WAM SYSTEM}

There are three basis for requiring a WAM system in a room or building. First. there must be a potential to exceed $2 \%$ of any Annual Limit of Intake (ALI). Second, if the $2 \% \mathrm{ALI}$ is exceeded, it must be breathed by a person who is there as part of a normal/routine work assignment. Third, the potential to exceed $2 \%$ of any ALI must be from a single failure or abnormal event to result in worker exposure. A11 three basis must be present for a WAM system to be required.

There must be a potential for a worker to be exposed to one Derived Air Concentration (DAC) in a room/building over a prolonged period of time for continuous air monitoring, i.e., installation of a continuous air monitor (CAM), to be required.

\subsubsection{Potential to Exceed $2 \%$ of ALI}

The potential to exceed $2 \%$ of any ALI is evaluated by reviewing historical and current airborne radioactivity data and by calculating potential airborne radioactivity concentrations based on source terms available and possible single failure events. The potential for a worker to exceed $2 \%$ of ALI is also dependent on the amount of time spent in the room or building and is the limiting factor at occupancies greater than 96 minutes per day ( 90 minutes for simplicity). For 90 minutes or less occupancy, the potentia? for $2 \%$ of ALI wi 11 not be reached before $10 \%$ DAC, at which time air sampling will be performed and respiratory 
HNF-SD-W026-TA-002

Revision 2

Page 7 of 41

protection would be used in most cases. Source terms include radioactive materials being used or transported in the building or room and surface contamination levels present in equipment (e.g., gloveboxes) and on floors. If airborne radioactivity data or calculations indicate $2 \%$ of any ALI has been or could be exceeded, the first basis for requiring a sampling program pertains to the building or room in question.

\subsubsection{Personnel Present}

If the building or room is occupied or traversed by personnel as part of their normal/routine job. the second basis is met. "Occupied" is defined as 96 minutes (90 for simplicity), or greater. per day from Attachment 1 of Radiation Protection Technical Basis TBTN\#CDGH-9608-MCC-0079, CDMP Work Place Air Monitoring Standards. Any area with an occupancy rate greater than $96 \mathrm{~min} /$ day ( $8 \mathrm{~h} / \mathrm{wk}, 104 \mathrm{~h} / \mathrm{gtr}, 416 \mathrm{~h} / \mathrm{yr}$. etc.) but less than $2000 \mathrm{~h} / \mathrm{yr}$ is infrequently occupied. $2000 \mathrm{~h} / \mathrm{yr}$ represents continuous occupancy.

\subsubsection{Single Failure or Abnormal Event}

Historical data and industry data such as component failure rate information are used to evaluate the possibility that a single failure could result in airborne radioactivity concentrations that could cause an individual to exceed $2 \%$ ALI.

The potential for an abnormal event is determined through review of existing safety analysis documents and, where necessary, by room or building-specific safety evaluation.

\subsection{BASIS FOR DECLARING WAM NOT REQUIRED}

If any of the three basis for requiring a sampling system is not present, then a sampling system is not required.

\subsubsection{No Potential to Exceed 2\% of ALI}

If there is no potential to exceed $2 \%$ of ALI, a sampler is not required. Reasons why no potential exists include no radioactive material present, radioactive material is in a form that will not produce any or sufficient airborne contamination to exceed $2 \%$ of any ALI.

For surface contamination, the concentration present must be less than that required to produce $2 \%$ of a DAC (which wouTd result in $2 \%$ ALI if an exposure is for an entire working year of 2000 hours). Using the $1 \mathrm{E}-06 / \mathrm{m}$ resuspension 
HNF-SD-W026-TA-002

Revision 2

Page 8 of 41

factor (a different value may be used for specific nuclides and material forms when empirical data is available) the surface contamination required to achieve $2 \%$ of DAC in a room is $880 \mathrm{dpm} / 100 \mathrm{~cm}^{2}$ alpha (based on Pu-239) and $8.8 \times 10^{5}$ $\mathrm{dpm} / 100 \mathrm{~cm}^{2}$ beta-gamma (based on $\mathrm{Sr}-90$ ). These values assume the required surface contamination is present over the entire horizontal surface area of the room.

\subsubsection{Personne1 not Routinely Present}

If personnel are not routinely present (not more than 90 minutes per day), a sampling system is not required. Areas entered only to take periodic (not more often than daily) samples or periodicaliy record instrument readings are generally considered to not require WAM systems. [NOTE: For respiratory protection purposes. monitoring of any job where the potential exists to exceed 10\% of DAC. using instrumentation specified by Radiological Control, is required regardless of the time the job takes.]

\subsubsection{No Single Failure or Event}

A WAM system is not required in any room or building where two or more engineered barriers exist between the potential source and the individual. The two barriers can be structural and/or physical and must prevent release of material to the breathing zone of the worker. Examples of barriers include gloveboxes, directed air flow, closed source material containers, etc.

\subsection{BACKGROUND}

\subsection{GENERAL}

The effort to bring workplace air monitoring programs into compliance with applicable changes in the requirements began with; FDH, Radiation Protection Technical Basis TBTN\#PBGH-9608-MCC-0062. PIC Work Place Air Monitoring and FDH. Radiation Protection Technical Basis TBTN\#CDGH-9608-MCC-0079, COMP Work Place Air Monitoring Standards. Further. HNF-PRO-331 Work Place Air Monitoring was established in September 1997 to give the process for establishing facility workplace air monitoring programs that comply with the requirements of 10 CFR 835, G-10 CFR 835/E2, DOE/EH-0256T, and HSRCM-1. This document assesses workplace air monitoring with the requirements in that publication. 


$$
\begin{array}{r}
\text { HNF-SD-W026-TA-002 } \\
\text { Revision } 2 \\
\text { Page } 9 \text { of } 41
\end{array}
$$

\subsection{WRAP}

WRAP is located at the northwest quadrant of the 200 West area. It receives Low Level and Transuranic Waste for isotopic certification and processing.

\subsection{WRAP WORKPLACE AIR MONITORING PROGRAM}

\subsection{GENERAL}

The WRAP facility provides isotopic certification and processing of Low Leve1 Waste (LLW) and Transuranic Waste (TRU) in both drum and box formats. Isotopic certification is performed on newly generated TRU and suspect TRU for the Hanford Site. LLW \& TRU in drums is processed through gloveboxes as part of verification efforts or to remove prohibited items from that waste stream.

\section{1 .1 BUILDING 2336-W}

Building 2336-W consists of three principal areas of operation. These areas are: Shipping/Receiving Area Rm 101. Non-Destruction Examination/Non-Destructive Assay (NDE/NDA) Area Rm 104, and the Process Area Rm 107. The shipping/receiving area is where waste containers are received/shipped and includes the TRUPACT loading area. The NDE/NDA area houses the examination and assay systems for waste drums and boxes. The process area contains gloveboxes for processing drummed LIW or TRU. See page 24 for the $2336-W$ facility layout.

\section{1 .2 BUILDING $2740-\mathrm{W}$}

Building 2740-W is the administrative support building for WRAP. This building contains most of the offices for the personnel of WRAP. See page 23 for the WRAP complex layout.

\subsubsection{BUILDING $2620-W$}

Building $2620-\mathrm{W}$ is the maintenance support building for WRAP. This building contains the shops for maintenance personnel. See page 23 for the WRAP complex layout. 
HNF-SD-W026-TA-002

Revision 2

Page 10 of 41

\subsection{WORKPLACE AIR MONITORING PROGRAM}

Currentiy, the WRAP workplace air monitoring program consists of fixed-head samplers and continuous air monitors in rooms with significant quantities of radioactive materials. The samples are collected and analyzed on a week ly basis for gross alpha and gross beta activity. The locations of the samplers are shown in Table 1. Air sample results from March 3. 1997 (prior to phase 1 startup of WRAP) to present time are available from the radiological control organization.

Table 1: Location of WRAP Air Samplers

\begin{tabular}{|c|c|c|c|}
\hline EDP Code & Location & Type of Sampler & Component Number \\
\hline W-151 & Shipping/Receiving & Beta CAM & 12-RITA-515 \\
\hline$W-152$ & Shipping/Receiving & Alpha CAM & 12-RITA-511 \\
\hline W-153 & NDE/NDA & Beta CAM & 12-RITA-514 \\
\hline W-154 & NDE/NDA & Alpha CAM & 12-RITA-510 \\
\hline W-155 & Process Area South & Beta CAM & $\overline{12-R I T A-544}$ \\
\hline W-156 & Process Area South & Alpha CAM & 12-RITA-509 \\
\hline W-157 & Process Area North & Beta CAM & 12-RITA-513 \\
\hline$W-158$ & Process Area North & Alpha CAM & 12-RITA-545 \\
\hline$W-159$ & Process HVAC & Beta CAM & 12-RITA-516 \\
\hline$W-160$ & Process HVAC & Alpha CAM & 12-RITA- 512 \\
\hline W-165 & LLW RWM Operator Air Sampler & Fixed Head & $12-\mathrm{RE}-538 \mathrm{~A}$ \\
\hline$W-166$ & LLW RWM Operator Air Sampler & Fixed Head & $12-R E-538 B$ \\
\hline $\mathrm{W}-167$ & TRU RWM Operator Air Sampler & Fixed Head & 12-RE-539A \\
\hline $\mathrm{W}-168$ & TRU RWM Operator Air Sampler & Fixed Head & $12-R E-539 B$ \\
\hline$W-169$ & LLW Line Operator Air Sampler & Fixed Head & $12-R E-540 A$ \\
\hline$W-170$ & LLW Line Operator Air Sampler & Fixed Head & $12-R E-540 B$ \\
\hline$W-171$ & LLW Line Operator Air Sampler & Fixed Head & $12-R E-540 C$ \\
\hline$W-172$ & LLW Line Operator Air Sampler & Fixed Head & $12-R E-5400$ \\
\hline $\mathrm{W}-173$ & TRU Line Operator Air Sampler & Fixed Head & $12-R E-541 A$ \\
\hline$W-174$ & TRU Line Operator Air Sampler & Fixed Head & $12-R E-541 B$ \\
\hline W- 175 & TRU Line Operator Air Sampler & Fixed Head & 12-RE-541C \\
\hline$W-176$ & TRU Line Operator Air Sampler & Fixed Head & $12-R E-5410$ \\
\hline$W-177$ & TRU Line Operator Air Sampler & Fixed Head & $12-R E-541 E$ \\
\hline$W-178$ & TRU Line Operator Air Sampler & Fixed Head & $12-\mathrm{RE}-54 \mathrm{IF}$ \\
\hline$W-179$ & 302 Glovebox Operating Side & Alpha CAM & $12-$ RITA- 590 \\
\hline$W-180$ & 308 Glovebox Operating Side & Alpha CAM & 12-RITA-591 \\
\hline$W-181$ & 302 Glovebox Maintainence Side & Alpha CAM & 12 -RITA-592 \\
\hline W-182 & 102 Glovebox Maintainence Side & Beta CAM & 12-RITA-593 \\
\hline
\end{tabular}


HNF-SD-W026-TA-002

Revision 2

Page 11 of 41

\begin{tabular}{|l|l|l|l|}
\hline W-183 & 102 Glovebox Operating Side & Beta CAM & 12-RITA-594 \\
\hline W-184 & 201 Glovebox & Beta CAM & 12-RITA-595 \\
\hline W-185 & 401 Glovebox & Alpha CAM & 12-RITA-596 \\
\hline
\end{tabular}

A review of baseline air sample data collected for the past two years demonstrated that routine operations may generate airborne radioactivity in excess of the trigger level. It must be noted that as WRAP continues to ramp-up to full production. air sample concentrations may vary due to increased operational activities in the process area. The review consisted of comparing the maximum alpha and beta airborne radioactivity levels reported for this period with the levels required to achieve an exposure of 40 DAC-hours. (An exposure of 40 DAC-hours wi 11 result in an intake of $2 \%$ of an ALI). It can be shown that the exposure (in DAC-hours) for an airborne radionuclide can be calculated from the following equation:

Exposure $(\mathrm{DAC}$-hours $)=\quad$ Airborne Concentration $(\mathrm{uCi} / \mathrm{ml}) \times$ [Occupancy (hours/yr) / DAC $(\mathrm{uCi} / \mathrm{m} \mathrm{l})$ ]

The total exposure would be obtained from summation of all contributing radionuclides. For WRAP, the limiting DAC values for alpha and beta emitters are those for Plutonium-239 and Strontium-90, respectively. This calculation was performed for each sampling location using the maximum alpha and beta activites from March 3, 1997 through September 30, 1998. The results are presented in Table 2, below.

Table 2: Potential Exposure based on maximum observed activity

\begin{tabular}{|l|l|l|l|}
\hline EDP Code & Alpha Activity (uCi/ml) & Beta Activity (UCi/ml) & Exposure(DAC-hours) \\
\hline$W-151$ & $5.40 E-14$ & $1.17 \mathrm{E}-13$ & 54.2 \\
\hline$W-152$ & $4.80 \mathrm{E}-14$ & $2.34 \mathrm{E}-13$ & 48.2 \\
\hline$W-153$ & $3.70 \mathrm{E}-14$ & $7.80 \mathrm{E}-14$ & 37.1 \\
\hline$W-154$ & $1.52 \mathrm{E}-14$ & $2.70 \mathrm{E}-13$ & 15.5 \\
\hline$W-155$ & $1.50 \mathrm{E}-14$ & $1.88 \mathrm{E}-13$ & 15.2 \\
\hline$W-156$ & $1.10 \mathrm{E}-13$ & $2.70 \mathrm{E}-14$ & 110.3 \\
\hline$W-157$ & $2.16 \mathrm{E}-15$ & $2.40 \mathrm{E}-14$ & 2.2 \\
\hline$W-158$ & $1.40 \mathrm{E}-13$ & $5.10 \mathrm{E}-13$ & 140.5 \\
\hline$W-159$ & $4.80 \mathrm{E}-15$ & $2.68 \mathrm{E}-14$ & 0.6 \\
\hline$W-160$ & $5.58 \mathrm{E}-15$ & $3.18 \mathrm{E}-14$ & 0.7 \\
\hline$W-165$ & $3.24 \mathrm{E}-15$ & $1.10 \mathrm{E}-13$ & 3.4 \\
\hline
\end{tabular}




\begin{tabular}{|c|c|c|c|}
\hline EDP Code & Alpha Activity (uCi/ml) & Beta Activity (uCi/mI) & Exposure(DAC-hours) \\
\hline$W-166$ & $4.62 E-15$ & $2.77 \mathrm{E}-14$ & 4.6 \\
\hline$W-167$ & $2.5 \overline{7 E-15}$ & $2.55 \mathrm{E}-14$ & 2.6 \\
\hline W-168 & $3.33 \mathrm{E}-15$ & $7.36 \mathrm{E}-14$ & 3.4 \\
\hline$W-169$ & $1.86 \bar{E}-15$ & $1.07 \bar{E}-13$ & 2.0 \\
\hline $\bar{W}-170$ & $3.14 \mathrm{E}-15$ & $6.05 E-14$ & 3.2 \\
\hline W-171 & $3.00 \mathrm{E}-14$ & $5.30 \bar{E}-14$ & 30.1 \\
\hline$W-172$ & $4.45 \bar{E}-15$ & $3.20 E-14$ & 4.5 \\
\hline $\mathrm{W}-1 \overline{73}$ & None Observable & $2.70 \bar{E}-14$ & 0.1 \\
\hline W-174 & $2.63 E-15$ & $4.44 \mathrm{E}-14$ & 2.7 \\
\hline$W-17 \overline{5}$ & $2.98 \mathrm{E}-15$ & $9.51 E-14$ & 3.1 \\
\hline W-176 & $2.62 \bar{E}-15$ & $3.54 \mathrm{E}-14$ & 2.7 \\
\hline$W-177$ & $6.20 E-15$ & $2.69 E-14$ & 6.2 \\
\hline W-178 & $6.20 \mathrm{E}-15$ & $2.95 E-14$ & $6 . \overline{2}$ \\
\hline$W-179$ & $1.60 \mathrm{E}-13$ & $4.80 E-13$ & 160.5 \\
\hline$W-180$ & $2.80 E-13$ & $6.90 \overline{E-13}$ & 280.7 \\
\hline $\bar{W}-181$ & 1.30 E-13 & $8.30 E-13$ & 130.8 \\
\hline W-182 & None Observable & $1.85 \mathrm{E}-14$ & 0.1 \\
\hline$W-183$ & $5.80 \mathrm{E}-15$ & $2.20 E-14$ & 5.8 \\
\hline$W-184$ & $2.70 E-15$ & $1.32 \mathrm{E}-15$ & 2.7 \\
\hline W-185 & $1.30 \mathrm{E}-13$ & $2.60 \mathrm{E}-13$ & $\overline{130.3}$ \\
\hline
\end{tabular}

It must be noted that the results of table 2 are not reflective of any actual internal exposures at WRAP. Using the maximum observed concentration at a location is an extremely conservative approach to access the criteria of $2 \%$ ALI (40 DAC-hrs) for WAM.

\subsection{BUILDINGS/ROOMS THAT REQUIRE WAM}

Based upon the Workplace Air Monitoring Evaluation (Attachment 1), there are three areas in the $2336-W$ building that require WAM. They are; the Shipping/Receiving Area, the NDE/NDA Area, and the Process Area. In the annual updates to this document: need. placement, and upgrades as necessary will be evaluated. The following instruments wi7l be used as the WAM system for WRAP: 
HNF-SD-W026-TA-002

Revision 2

Page 13 of 41

\section{6-W/Room 101}

This is the primary storage area for waste containers. Normal operations include; off loading waste containers from trucks, movement of waste containers by fork 1 ifts. utilizing drum grappling devices from cranes and powered equipment, and assembTing drums into TRUPACTS. During an accident scenario, the potential to release radioactive materials is credible. Since people must work in close proximity to the containers, they may be exposed to radiological hazards. The potential dose from an unplanned release (mechanical, fire, explosion or earthquake) could be up to a REM HNF-SO-W026-SAR-002 Waste Receiving and Processing Facility Final Safety Analysis Report (SAR) Section 3.3.2.3.3. Worker Protection. The initiation frequency from table 3-18 of the SAR is $1.00 \mathrm{E}+00 / \mathrm{yr}$ for a mechanical breach. Other accidents have much smaller initiation frequencies but have similar consequences. This mechanical breach accident is the bounding case for unplanned release for room 101. A dose of one rem would equate to 400 DAC-hrs, greatly exceeding the criteria of 4 DAC-hrs for an unplanned release in a 4 hour working shift. Continuous Air Monitoring to alert workers of elevated airborne activity levels is required.

Currently two CAMs are located along the North wall of room 101. The PNNL Air Flow Evaluation for this room recommended that the air samplers be located in the West end of the room near potential release points. Using Table 1 of HNF-PRO-331, the purpose of sampling/monitoring in room 101 is to provide early warning of elevated airborne release(s). Placement of these CAMs should be between worker(s) and release points. Therefore the new proposed location for the CAMs are near the empty drum conveyor. The proposed location is on the air flow map (page 19). Engineering Change Notice 639520 has been initiated to move these CAMs to the proposed locations. 
HNF-SD-W026-TA-002

Revision 2

Page 14 of 41

2336-W/Room 104

This is the examination area by non-destructive means for waste containers. Normal operations include; non-destructive examination/nondestructive assay of drums and boxes. The accident scenarios are identical for this room as for room 101. Also, the ventilation system for this room is shared with room 101 . This ventilation system utilizes recirculation to supplement the supply ventilation. Therefore, for these and the reasons stated for room 101, Continuous Air Monitoring is required.

Currently two CAMs are located along the Automated Guided Vehicle (AGV) Aisle between the drum NDE and drum NDA units. The PNNL Air Flow Evaluation for this room reported that based on the air flow patterns observed both with the ventilation on and off, that the current air sampler locations appear to be adequate. The locations of the air samplers is included on the air flow map (page 20).

\section{6-W/Room 107}

This is the glovebox processing area for drum waste containers. Normal operations include: operating the four glovebox lines, lag storage of drum waste containers, and various maintenance activities outside of the glovebox enclosures (warm maintenance room). During an accident scenario, the potential to release radioactive materials is credible. Since people must work in close proximity to the containers (through glove ports and hands on with newly generated waste containers) they may be exposed to radiological hazards. The potential dose from an unplanned release (mechanical, fire, explosion or earthquake) could be up to a rem (SAR Section 3.3.2.3.3. Worker Protection). The scenario with the greatest potential would be a drum explosion in a process area outside the gloveboxes, but the frequency of occurrence of a drum explosion from table 3-19 of the SAR is 2.00 E-03/yr. An annualized dose from this accident would be less than $2.5 \mathrm{mrem}$ ( 1 DAC-hr). To evaluate the process area properly, the mechanical release scenario will be applied. The mechanical release scenario is based for the shipping/receiving area but is bounding for facility operations. Particularly of interest is the load out of compliant waste back into 2081 ( 55 gallon) and 3221 ( 85 gallon) drums. At these locations, full waste containers do not have their respective lids securely fastened. That evolution happens once the drums are away from the glovebox. Therefore, the mechanical release scenario will be 
HNF-SD-W026-TA-002

Revision 2

Page 15 of 41

used to determine if the 4 DAC-hr criteria is met for Continuous Air Monitoring. The initiation frequency from table 3-18 of the SAR is 1.00 $\mathrm{E}+00 / \mathrm{yr}$ for a mechanical breach. A dose of one rem would equate to 400 DAC-hrs, greatly exceeding the criteria of 4 DAC-hrs for an unplanned release in a 4 hour working shift. Continuous Air Monitoring to alert workers of elevated airborne activity levels is required.

Currently eleven CAMs are located throughout the room and at exhaust points. Also, fourteen breathing zone air samplers are located on the four glovebox lines to provide sampling of the confinement barrier (gloveboxes). The Air Flow Evaluation for this room stated that the current locations for the exhaust point CAMs for the room were adequate for the observed air flow patterns (see page 22 for air flow patterns and instrument locations). Those CAMs were positioned to detect airborne concentrations from various release points: Additionally, individual work locations have CAMs based on work activity being performed. Using Table 1 of HNF-PRO-331, there are four purposes for sampling/monitoring in room 107. They are: to provide early warning of elevated airborne release(s), determine total concentration from many potential release points, test for leakage of radioactive materials from sealed confinement systems, and determine airborne radioactivity area status or respiratory protection adequacy. CAMs are placed near the exhaust points to account for the many different release points. The fourteen breathing zone air samplers are located at strategic points on the gloveboxes to identify area needing confinement control and to be used as a backup to internal dosimetry results for worker's intake. The seven "worksite" CAMs are positioned near particular work areas to detect elevated airborne levels due to the activities performed. Finally, portable grab samplers will be used on a case-by-case basis for determining airborne radioactivity area status and respiratory protection adequacy for particular evolutions. Grab Air Sampling will be performed based on the technical work document (Work package, procedure, work plan, test document, etc.) and the Radiological Work Permit.

Worksite CAM placement: Seven CAMs are placed in the process area to cover areas of likely exposure to airborne radioactivity based on credible contamination spreads from gloveboxes and entry/exit ports. These placements are described below. 
HNF-SD-W026-TA-002

Revision 2

Page 16 of 41

IRU Process Line Operations Platform: One Alpha CAM on the operating side of the TRU process 7 ine shortly upstream in the ventilation path from the drum entry/exit port. This placement ensures that a release that resulted in airborne radioactivity exposure to personnel on the operations platform would be detected.

TRU Process Line Operations Platform: One Alpha CAM near the sorting area of the TRU line, where a glove rupture could result in an airborne release of radioactive material.

Back of TRU Process Line: Though routine operations do not occur on this side of the TRU process line, glovebox maintenance activities require the use of gloves and other process ports. An Alpha CAM is placed downstream in the ventilation path from most of these activities. Activities further down the TRU line are closer to (and upstream in the ventilation flow path from) the Alpha CAM originally installed at the west wall in the process area. This CAM at the back of the TRU process line monitors the corridor between it and the LLW process line, an area with relatively low ventilation velocity.

Operations Platform of LLW Process Line: One Beta CAM is placed downstream in the ventilation flow path of the entry/exit port and the supercompactor. Potential releases from process ports further down the process 7 ine are monitored by the Beta CAM originally placed on the west wa11 of the room.

Back of LLW Process Line: This placement mirrors the Alpha CAM placement on the back of the TRU 1ine, though ventilation velocity here is relatively high. This CAM monitors maintenance activities using gloves and other process ports in the LLW line.

IRU Restricted Waste Manaqement (RwM) Process Line: This process 1 ine is raised above the level of the platform, with open space beneath. The videotape of the original smoke testing showed that the ventilation flow strongly moved air from the breathing zone to the open space under the process line. Releases from glove ruptures would likely be drawn to the Alpha CAM which is placed approximately in the center of the line. This process line is on the west side of the room, and releases occurring downistream of the CAM would be detected by the Alpha CAM originally placed at the west wall (south side). 
HNF-SD-W026-TA-002

Revision 2

Page 17 of 41

LLW RWM Process Line: Placement of a Beta CAM under the LLW RWM process line mirrors the placement of the Alpha CAM under the TRU RWM process line.

This placement of these CAMs reflects a conservative approach to continuous air monitoring. Placement of each was intended to result in early warning of releases of airborne radioactivity, and actual personnel exposure to airborne radioactivity would in some cases be less than the concentration detected by the CAM.

\subsection{FILTER MEDIA SELECTION}

From HNF-PRO-331 Work Place Air Monitoring, facility radiological control must choose a filter media based on emission of concern and subsequent analysis method. Of the three approved filters, the VERSAPORE 3000 will be used at WRAP.

The Versapore 3000 is a $47 \mathrm{~mm}$ membrane (Acrylic copolymer) on a nylon support. This filter is chemically reactive and therefore can be used for destructive analysis. The collection efficiency for $0.3 \mu \mathrm{m}$ DOP at $32 \mathrm{1} /$ minute is 95.84 percent.

The Fluoropore is a $47 \mathrm{~mm}$ Teflon ${ }^{T M}$ membrane filter with a polypropylene support. This filter is not appropriate for destructive analysis. The collection efficiency for this filter is 99.99 percent as identified under DOE contract DEAC04-76EV01013. Sample collection occurs on the smooth side of this filter. As the two filter sides are nearly indistinguishable, facility personnel must take care to assure appropriate collection. Millipore manufactures these filters.

The air samples at WRAP will predominately be analyzed for both alpha and beta emissions. Since the Versapore 3000 can be used for destructive analysis, this is the filter of choice. However, for the application of alpha spectrometry (including Alpha CAMs with spectrometry software), Fluoropore FS sample media may be used. 


\section{HNF-SD-W026-TA-002 \\ Revision 2 Page 18 of 41}

\subsection{REFERENCES}

10 CFR 835, Occupational Radiation Protection.

DOE 5482.1B. Environmenta7. Safety, and Hea7th Appraisal Program.

G-10 CFR 835/E2, Workplace Air Monitoring.

HSRCM-1. Hanford Site Radiological Control Manual.

NUREG 1400, Air Sampling in the Workplace.

FOH, Radiation Protection Technical Basis TBTN\#PBGH-9608-MCC-0062, PIC Work Place Air Monitoring.

FDH. Radiation Protection Technical Basis TBTN\#CDGH-9608-MCC-0079. CDMP Work Place Air Monitoring Standards.

HNF-PR0-331 Work P7ace Air Monitoring

HNF-SD-W026-SAR-002. Waste Receiving and Processing Facility Final Safety Analysis Report.

Letter from Eva Eckert Hickey to Rick Swallow: Evaluation of Air Flow Patterns in Rooms 101 and 104 of the WRAP-1 Facility.

Letter from Mark Fishburn to Rick Swallow, 97MRF008; Evaluation of Air Flow Patterns in Rooms 107 and 113 of the WRAP Facility.

Letter 32640-98-DNS-055 from D. N. Stewart to J. R. Weidert: INTERIM TECHNICAL BASIS FOR CONTINUOUS AIR MONITORING IN THE WRAP PROCESSING AREA September 9 , 1998.

Letter 32640-98-DNS-061 from D. N. Stewart to L. W. Roberts: REVISED INTERIM TECHNICAL BASIS FOR CONTINUOUS AIR MONITORING IN THE WRAP PROCESSING AREA September 17, 1998. 


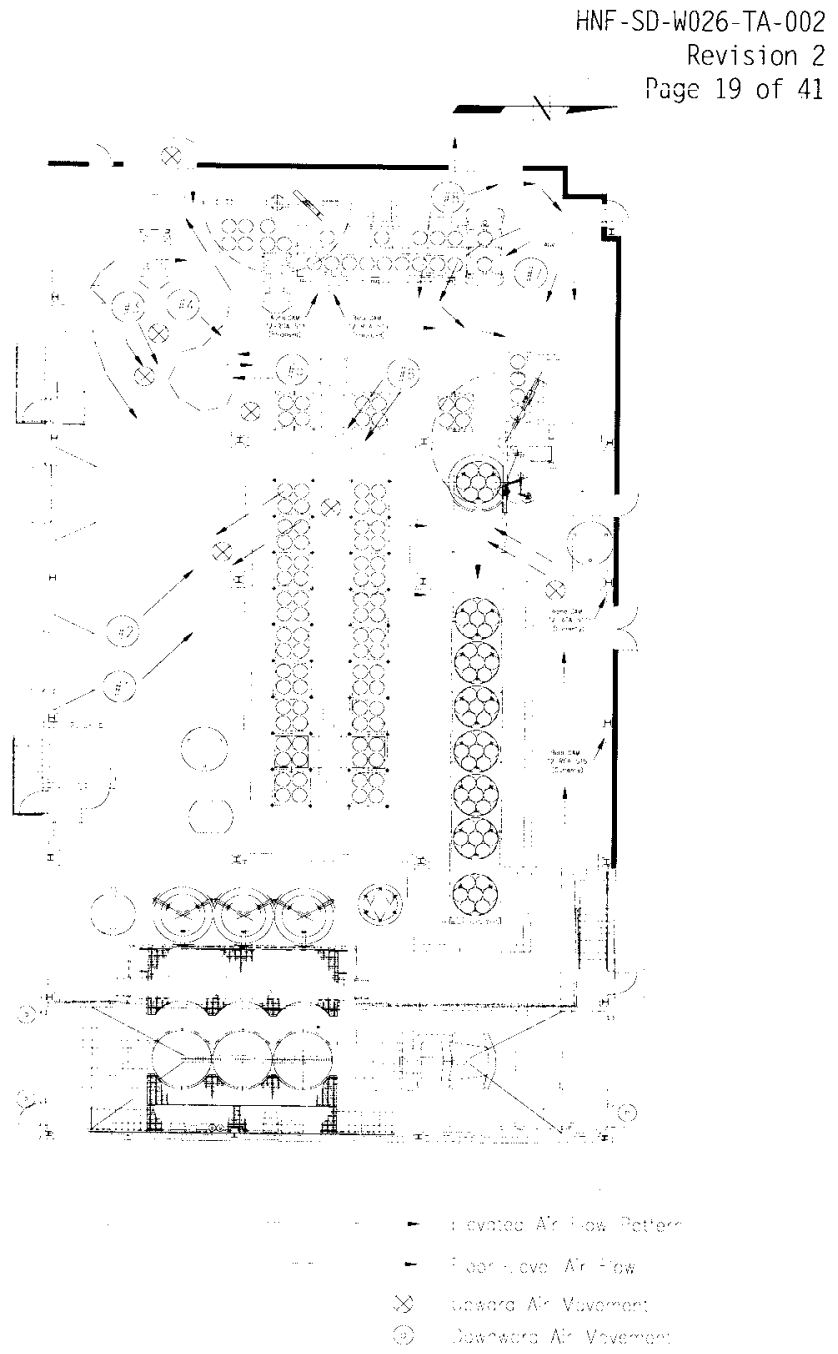

2336-W/Rm 101 Shipping/Receiving

Air Flow Patterns for WRAP (PNNL letter) 


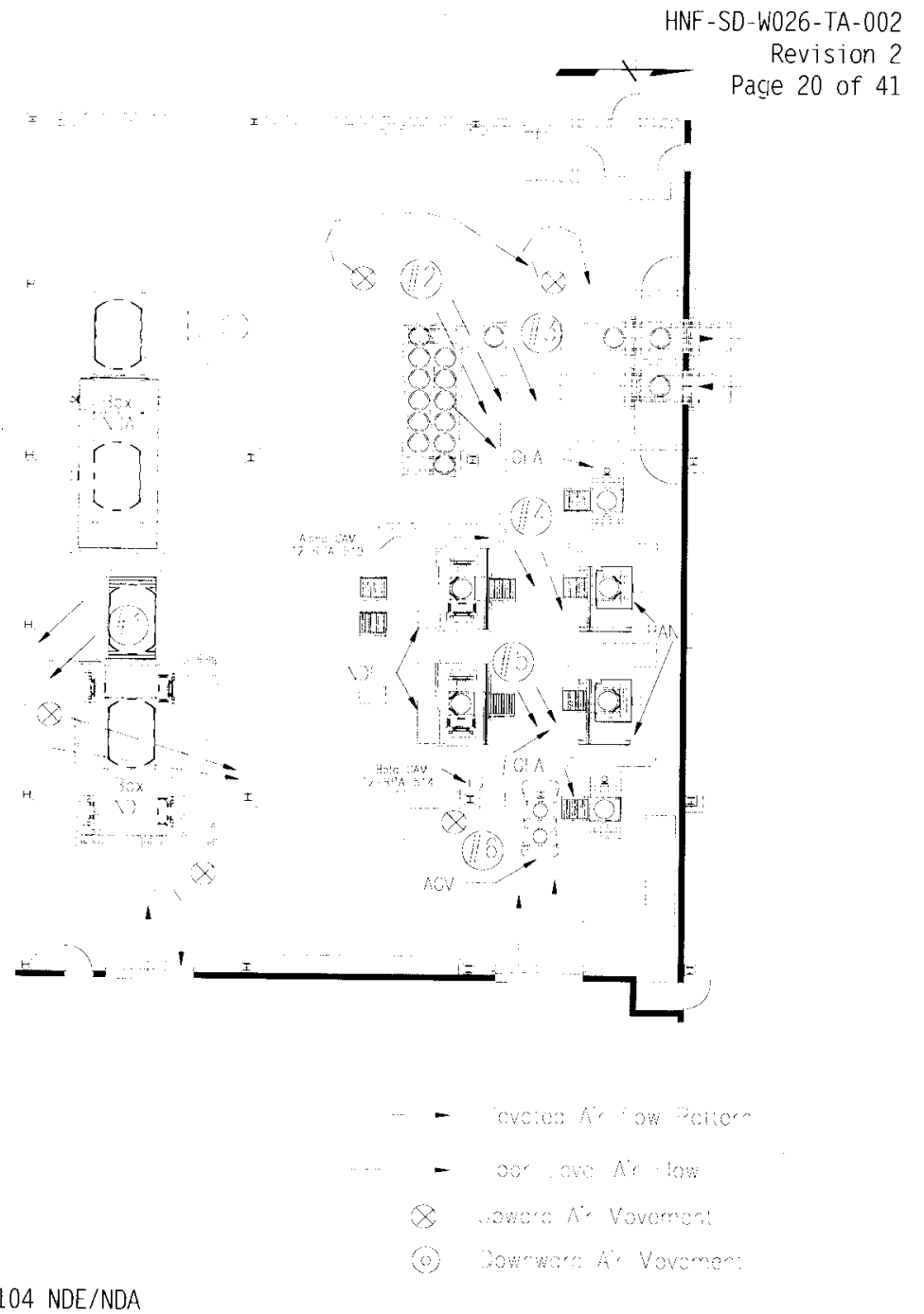

2336-W/Rm 104 NDE/NDA

Air Flow Patterns for WRAP (PNNL letter) 


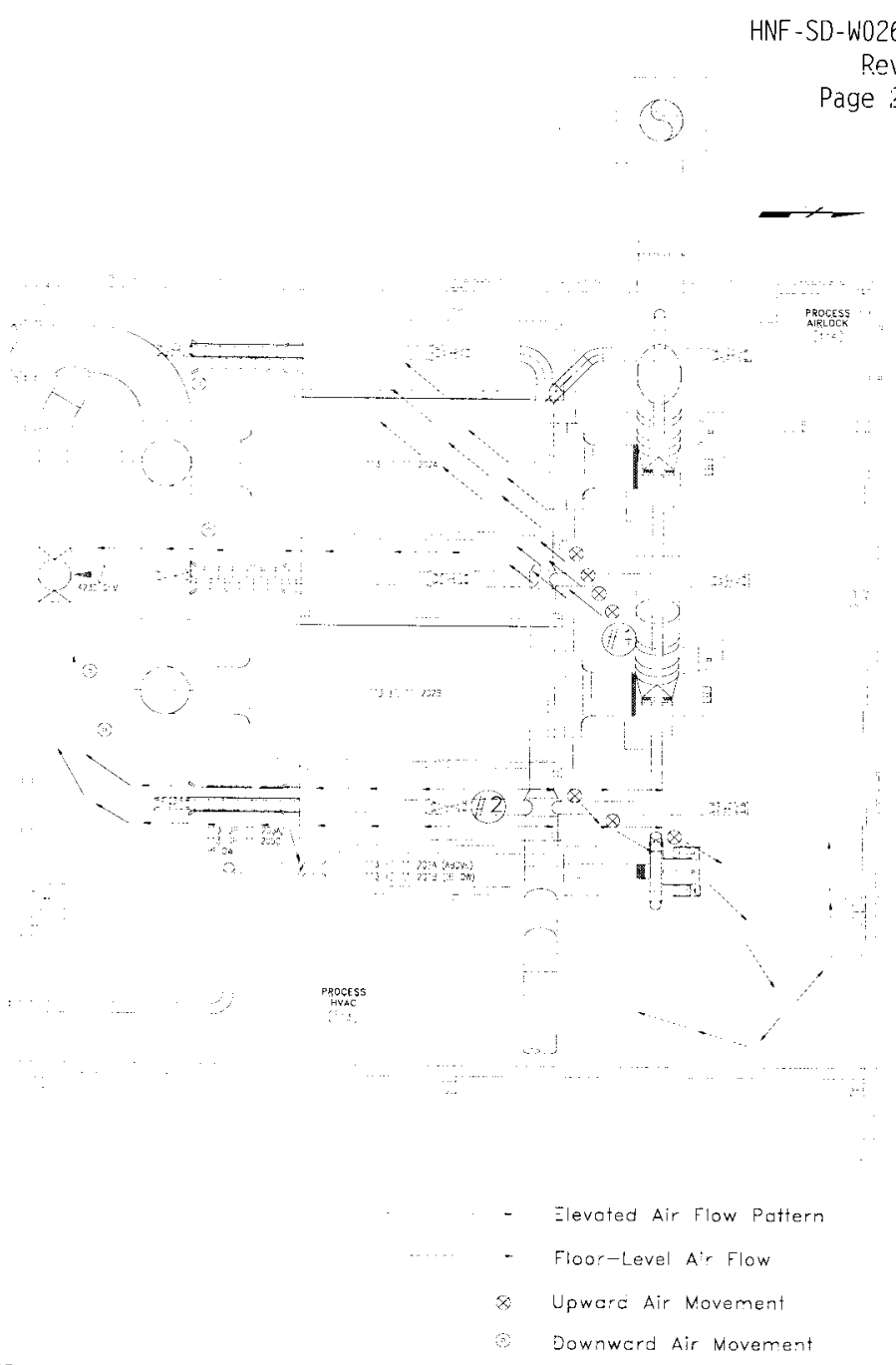

2336-W/Rm 113 Process HVAC

Air Flow Patterns for WRAP (97MRF008 letter) 


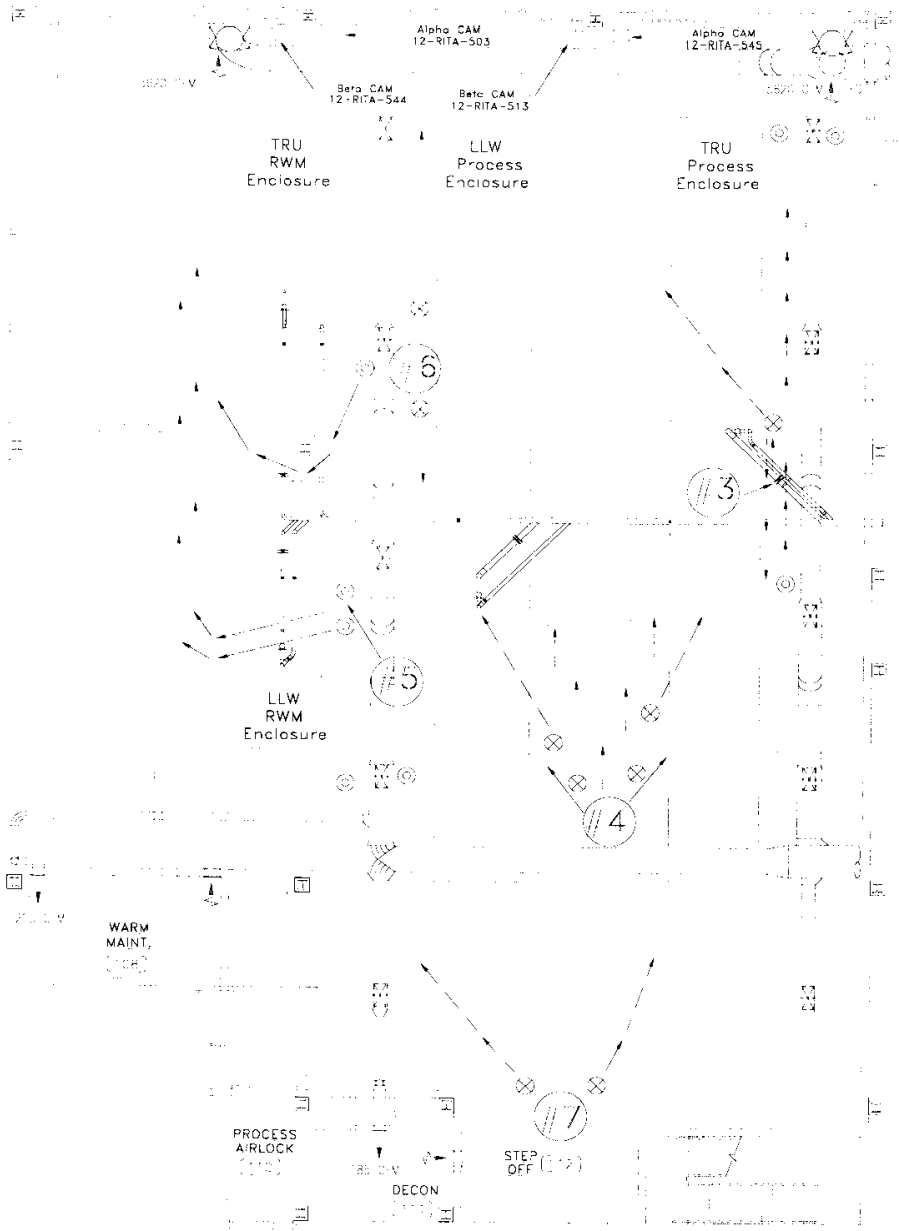

\footnotetext{
- Elevcted Air Flow Pattorn

- Floor-Level Air Flow

3 Upward Air Movement

(b) Downward Air Movernent
} 
HNF-SD-W026-TA-002

Revision 2

Page 23 of 41

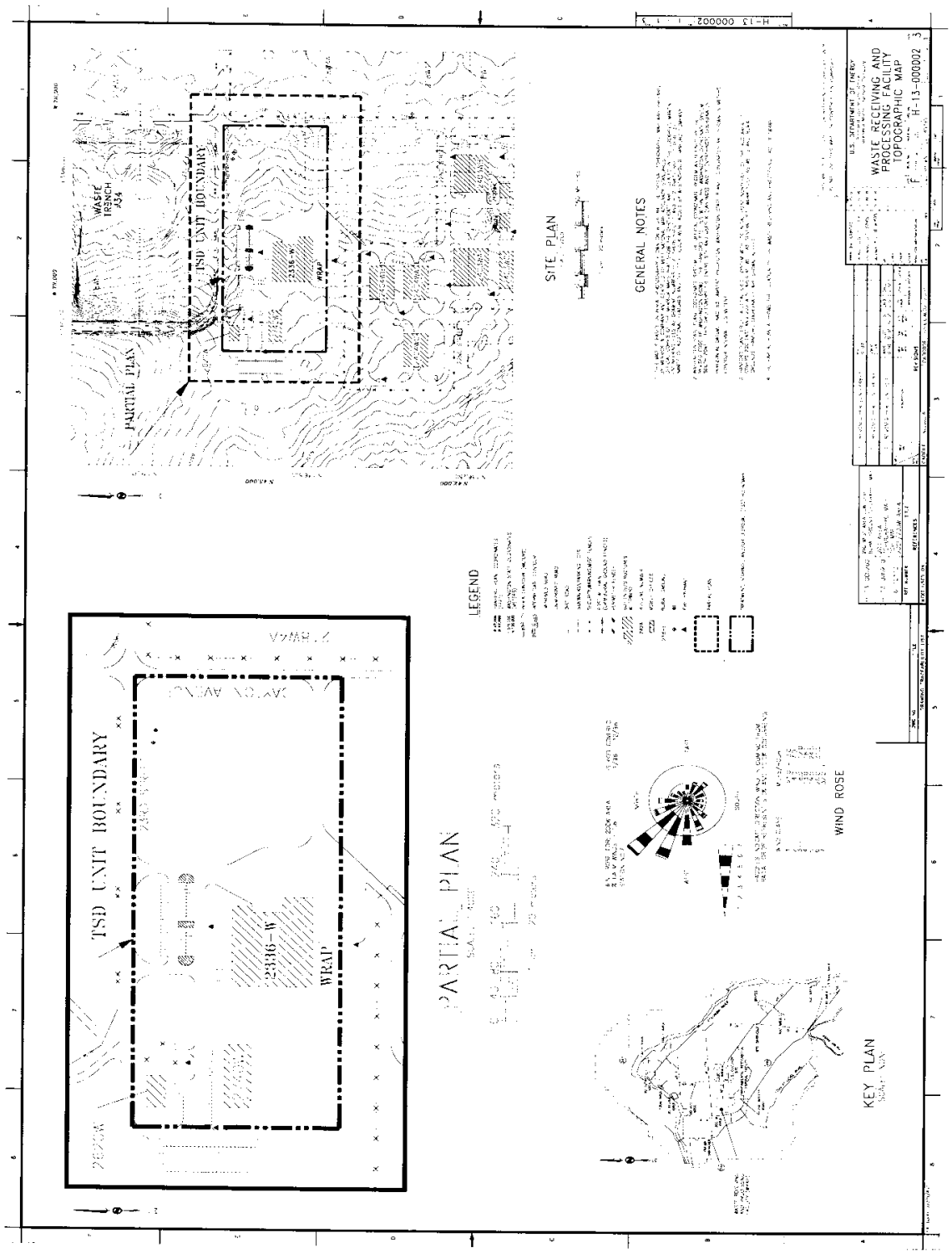


HNF-SD-W026-TA-002

Revision 2

Page 24 of 41

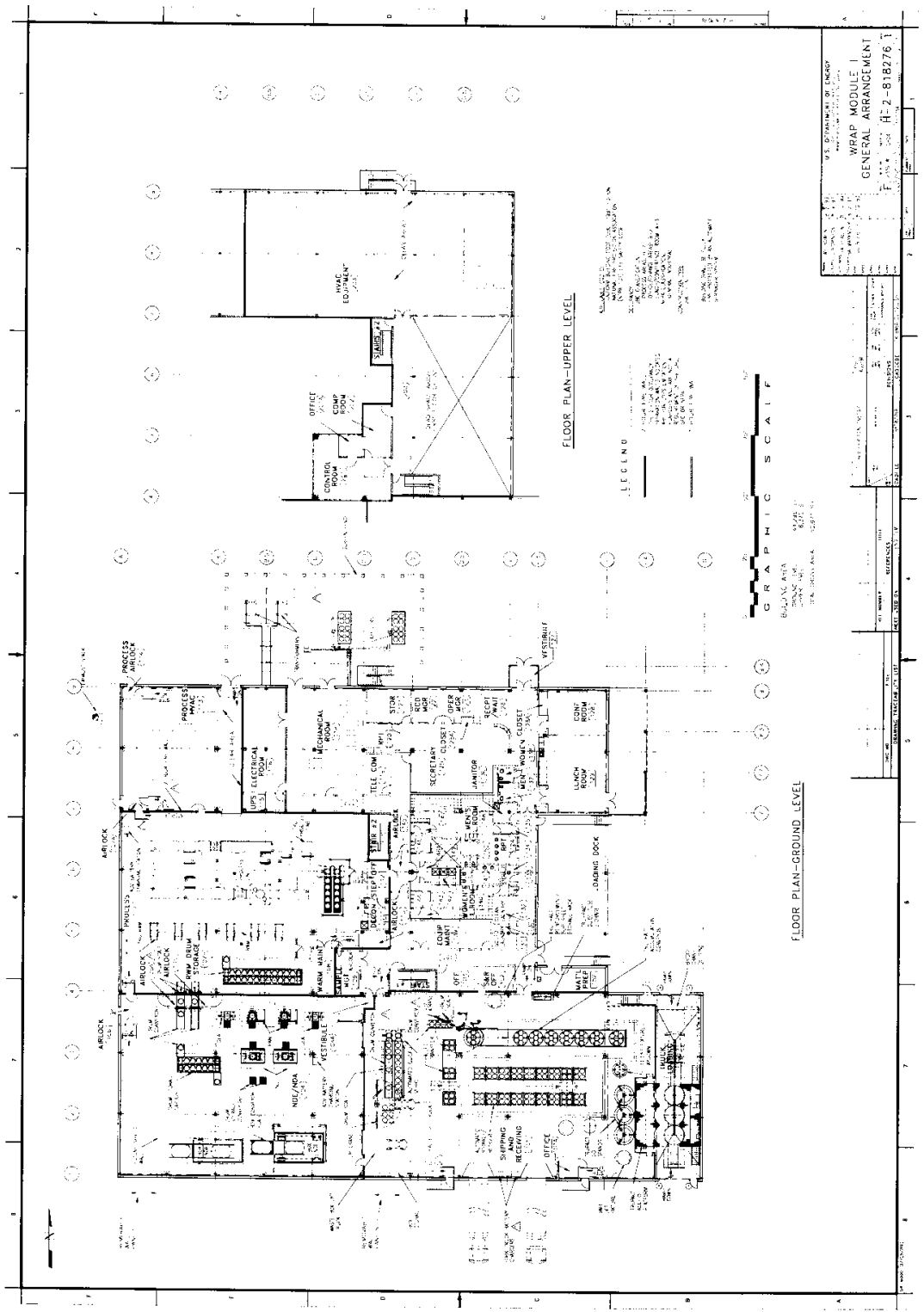




\subsection{Purpose}

The purpose of this attachment is to provide additional justification and background for the Workplace Air Monitoring (WAM) decisions placed forth in text of document HNF-SD-W026-TA-002.

\subsection{Criteria}

The criterion was previously described in the document. The following is a summary of what the Waste Receiving and Processing facility (WRAP) were evaluated against:

A.

Occupancy - areas which personnel are present greater than 90 minutes per day.

B.

Source Term - The presence of radioactive material.

C.

Potential to exceed $2 \%$ of an ALI - Ability of the source term to exceed $2 \%$ of an ALI to Personnel.

D.

Potential to exceed 8 DAC-hrs in a work shift ability of the source term to expose personne] to greater than 8 DAC-hrs in a working shift (an expected airborne exposure in contrast to an unplanned increase).

E.

Potential for a 4 DAC-hr unplanned increase in a working shift. (This is the determination level where a continuous air monitor is required in the workplace.)

\subsection{Evaluation}

Each of the buildings of the WRAP complex was evaluated against the criteria for WAM. The result for each category is summarized in the table concluding this attachment.

\section{Occupancy}

This requirement was addressed by performing an occupancy study of the fiftyeight rooms/areas of the WRAP complex. The study entailed interviews with first line supervisors for WRAP. Thirty-three rooms/areas were determined to meet the $90 \mathrm{~min} /$ day occupancy for further evaluation. Results of that study are presented in table 1.0 . 
Table 1.0 Occupancy Study

\begin{tabular}{|c|c|c|c|c|c|}
\hline Location & Description & $\begin{array}{c}\text { RCTs } \\
\text { hours/wk }\end{array}$ & $\begin{array}{c}\text { Time in } \\
\text { Area } \\
\text { Ops } \\
\text { hours/wk }\end{array}$ & $\begin{array}{l}\text { Maint. } \\
\text { hours/wk }\end{array}$ & $\begin{array}{c}\text { others } \\
\text { hours } / \text { wk }\end{array}$ \\
\hline $2620-W$ & Maintenance Support Building & 4 & 0 & 25 & 25 \\
\hline $2740 \cdot W$ & $\begin{array}{l}\text { Administrative Support } \\
\text { Building }\end{array}$ & 0 & 4 & 22.5 & 40 \\
\hline $\begin{array}{l}2336-\mathrm{W} / 100 \\
101,101 \mathrm{~A}\end{array}$ & $\begin{array}{l}\text { Truck Loading, } \\
\text { Shipping/Receiving and S/R } \\
\text { Office }\end{array}$ & 30 & 40 & 15 & 5 \\
\hline $2336-W / 102$ & Operations Office & 1 & 40 & 0.5 & 1 \\
\hline $2336 \cdot W / 103$ & Counting Office & 40 & 2 & 0.5 & 5 \\
\hline $\begin{array}{l}2336-W / 104 \\
104 A, 105 \\
105 A\end{array}$ & $\begin{array}{l}\text { NDE/NDA, Vestibule NDE/NDA, } \\
\text { Outfeed Airlock. Infeed } \\
\text { Airlock }\end{array}$ & 30 & 40 & 17.5 & 20 \\
\hline $2336-W / 106$ & NDE/NDA Airlock & 0 & 0 & 0.5 & 0 \\
\hline $\begin{array}{l}2336-W / 107 \\
108,111 \\
112\end{array}$ & $\begin{array}{l}\text { Process Area, Warm } \\
\text { Maintenance, Decon Station, } \\
\text { Step off }\end{array}$ & 40 & 40 & 20.5 & 25 \\
\hline $2336-W / 107 A$ & Process/Process HVAC Airlock & 0 & 4 & 3 & 0 \\
\hline 2336-W/109 & Sample Management & 0 & 4 & 0.5 & 10 \\
\hline $2336-W / 110$ & Process Equipment Airlock & 0 & 0 & 0.5 & 0 \\
\hline $2336-W / 113$ & Process HVAC Area & 4 & 2 & 5 & 1 \\
\hline $2336-W / 114$ & Process HVAC Airlock & 0 & 0 & 2.5 & 0 \\
\hline $2336 \cdot W / 115$ & UPS & 0 & 0 & 12 & 0 \\
\hline $2336 \cdot W / 116$ & Electrical & 0 & 0 & 9.5 & 1 \\
\hline $2336-w / 117$ & North Hallway & 1 & 1 & 5.5 & 1 \\
\hline $2336-W / 118$ & Mechanical & 0 & 2 & 10 & 1 \\
\hline $2336-W / 119$ & Telephone/Communications & 0 & 0 & 3 & 1 \\
\hline $2336 \cdot W / 120$ & Radcon Manager's Office & 40 & 2 & 1 & 40 \\
\hline $2336-W / 121$ & Operations Lead Office & 4 & 40 & 1 & 40 \\
\hline $2336 \cdot W / 122$ & Operations Manager's Office & 1 & 40 & 2.5 & 40 \\
\hline $2336 \cdot W / 123$ & Plant Manager's Office & 4 & 40 & 3 & 40 \\
\hline $2336-W / 124$ & ACES & 40 & 0 & 9 & 2 \\
\hline $2336-W / 125$ & Secretary Bay & 40 & 8 & 4.5 & 40 \\
\hline $2336-W / 125 A$ & Closet & 0 & 0 & 10 & 1 \\
\hline $2336 \cdot W / 126$ & Reception Area & 4 & 8 & 1.5 & 40 \\
\hline $2336-W / 127$ & Vestibule & 0 & 0 & 0.5 & 1 \\
\hline $2336 \cdot W / 128$ & Conference Room & 12 & 20 & 3 & 40 \\
\hline $2336-W / 128 A$ & Closet & 1 & 0 & 4 & 0 \\
\hline $2336 \cdot W / 129$ & Lunch Room & 7 & 8 & 7 & 12 \\
\hline $2336-W / 130$ & East Hallway & 1 & 2 & 8 & 1 \\
\hline
\end{tabular}


Time in

Area

RCTs Ops Maint. Others

\begin{tabular}{|c|c|c|c|c|c|}
\hline Location & Description & hours/wk & hours/wk & hours/wk & Hours/wk \\
\hline $2336-W / 131$ & Soiled Laundry & 0 & 1 & 0 & 0 \\
\hline $2336-W / 132$ & Mask Station & 0 & 1 & 0 & 0 \\
\hline $2336-W / 133$ & $\begin{array}{l}\text { Entryway to Women's Locker } \\
\text { Room }\end{array}$ & 0 & 0 & 0 & 0 \\
\hline $2336-W / 134$ & Storage & 0 & 0 & 0.5 & 0 \\
\hline $2336 \cdot W / 135$ & Entryway to Men's Locker Room & 0 & 0 & 16 & 0 \\
\hline $2336-W / 136$ & Janitor Room & 0 & 0 & 0 & 5 \\
\hline $2336-W / 137$ & Men's Restroom & 1 & 4 & 21 & 1 \\
\hline $2336-W / 138$ & Women's Restroam & 1 & 4 & 0 & 1 \\
\hline $2336 \cdot W / 139$ & Equipment Maintenance & 0 & 0 & 14.5 & 1 \\
\hline $2336-W / 140$ & Women's Locker Room & 1 & 4 & 0 & 1 \\
\hline $2336-W / 141$ & Women's Restroom & 1 & 4 & 0 & 1 \\
\hline $2336-W / 142$ & Women's Shower & 1 & 2 & 0 & 0 \\
\hline $2336-W / 143$ & $\begin{array}{l}\text { Entryway to Women's SWP Change } \\
\text { Area }\end{array}$ & 0 & 0 & 0 & 0 \\
\hline $2336-W / 144$ & Women's SWP Change Area & 1 & 2 & 0 & 0 \\
\hline $2336-W / 145$ & Process Area Personnel Airlock & 0 & 1 & 2.5 & 1 \\
\hline $2336-W / 146$ & Men's SWP Change Area & 1 & 2 & 13.5 & 1 \\
\hline $2336-W / 146 A$ & Storage & 0 & 0 & 0 & 0 \\
\hline $2336-W / 147$ & $\begin{array}{l}\text { Entryway to Men's SWP Change } \\
\text { Area }\end{array}$ & 0 & 0 & 3 & 0 \\
\hline $2336-W / 148$ & Men's Locker Room & 1 & 4 & 16 & 1 \\
\hline $2336-W / 149$ & Men's Shower & 1 & 2 & 4 & 1 \\
\hline $2336 \cdot W / 150$ & Men's Restroom & 1 & 4 & 16 & 1 \\
\hline $2336-W / 151$ & South Hallway & 0 & 1 & 3 & 1 \\
\hline $2336-W / 152$ & Material Preparation & 0 & 2 & 1 & 1 \\
\hline $2336-W / 200$ & Second Floor: Hallway & 0 & 0 & 10.5 & 1 \\
\hline $2336-W / 201$ & Control Room & 1 & 40 & 15.5 & 30 \\
\hline $2336-W / 201 A$ & Control Room Operator Station & 1 & 40 & 1.5 & 2 \\
\hline $2336 \cdot W / 202$ & Computer Room & 0 & 4 & 5 & 10 \\
\hline $2336-W / 203$ & HVAC Equipment & 0 & 4 & 17 & 4 \\
\hline
\end{tabular}

\section{Source Term}

Radioactive material that could be dispersed during operation or during an accident was considered as source term. All fifty-eight rooms/areas of the WRAP Complex considered in the evaluation. Only eight rooms/areas meet the source term requirement. Of those, only five meet the occupancy requirements. These five are: $2336-W / 100,101, \& 101 \mathrm{~A}, 2336-W / 104,104 \mathrm{~A}, 105, \& 105 \mathrm{~A}, 2336-W / 107$. 108. 111. \& 112. 2336-W/109, and 2336-W/146. 


\section{Potential to Exceed $2 \%$ of an ALI}

Each of the source terms were evaluated to determine if they have enough material to exposure the maximum exposed worker to $2 \%$ of an ALI. This was done by: evaluating air sample data and examining accidents from the SAR on a annualized basis.

\section{Potential to Exceed 8 DAC-hrs in a Working Shift}

Each room that had the potential to exceed $2 \%$ of an ALI was evaluated for an 8 DAC-hr exposure to the maximum exposed worker in a working shift. This is an expected exposure rather than a unplanned increase (accident). It must be noted that as WRAP continues to ramp-up to full production, air sample concentrations may vary due to increased operational activities in the process area. The review consisted of comparing the maximum alpha and beta airborne radioactivity levels reported for this period and propogated them over a 8 hour working shift. It can be shown that the exposure (in DAC-hours) for an airborne radionuclide can be calculated from the following equation:

Exposure $($ DAC-hours $)=\quad$ Maximum Airborne Concentration $(\mathrm{uCi} / \mathrm{ml}) \times$ [8 hrs / DAC (uCi/mi)]

The total exposure would be obtained from summation of all contributing radionuclides. For WRAP. the limiting DAC values for alpha and beta emitters are those for Plutonium-239 and Strontium-90, respectively. This calculation was performed for each sampling location using the maximum alpha and beta activites from March 3, 1997 through September 30, 1998. The results are presented in Table 2, below.

Table 2: Potential Exposure based on maximum observed activity

\begin{tabular}{|l|l|l|l|}
\hline EDP Code & Alpha Activity $(\mathrm{uC} / \mathrm{m}]$ ) & Beta Activity (uCi/ml) & Exposure (DAC-hours \\
\hline$W-151$ & $5.40 \mathrm{E}-14$ & $1.17 \mathrm{E}-13$ & 0.216468 \\
\hline$W-152$ & $4.80 \mathrm{E}-14$ & $2.34 \mathrm{E}-13$ & 0.192936 \\
\hline$W-153$ & $3.70 \mathrm{E}-14$ & $7.80 \mathrm{E}-14$ & 0.148312 \\
\hline$W-154$ & $1.52 \mathrm{E}-14$ & $2.70 \mathrm{E}-13$ & 0.06188 \\
\hline$W-155$ & $1.50 \mathrm{E}-14$ & $1.88 \mathrm{E}-13$ & 0.060752 \\
\hline$W-156$ & $1.10 \mathrm{E}-13$ & $2.70 \mathrm{E}-14$ & 0.44108 \\
\hline$W-157$ & $2.16 \mathrm{E}-15$ & $2.40 \mathrm{E}-14$ & 0.008736 \\
\hline$W-158$ & $1.40 \mathrm{E}-13$ & $5.10 \mathrm{E}-13$ & 0.56204 \\
\hline$W-159$ & $4.80 \mathrm{E}-15$ & $2.68 \mathrm{E}-14$ & 0.019307 \\
\hline$W-160$ & $5.58 \mathrm{E}-15$ & $3.18 \mathrm{E}-14$ & 0.022447 \\
\hline$W-165$ & $3.24 \mathrm{E}-15$ & $1.10 \mathrm{E}-13$ & 0.0134 \\
\hline$W-166$ & $4.62 \mathrm{E}-15$ & $2.77 \mathrm{E}-14$ & 0.018591 \\
\hline
\end{tabular}




\begin{tabular}{|c|c|c|c|}
\hline EDP Code & Alpha Activity $(\mathrm{uCi} / \mathrm{ml})$ & Beta Activity (uCi/ml) & Exposure (DAC-hours \\
\hline$W-167$ & $2.57 \mathrm{E}-15$ & $2.55 \mathrm{E}-14$ & 0.010382 \\
\hline$W-168$ & $3.33 E-15$ & $7.36 E-14$ & 0.013614 \\
\hline$W-169$ & $1.86 \mathrm{E}-15$ & $1.07 \mathrm{E}-13$ & 0.007868 \\
\hline$W-170$ & $3.14 E-15$ & $6.05 \mathrm{E}-14$ & 0.012802 \\
\hline$W-171$ & $3.00 E-14$ & $5.30 \mathrm{E}-14$ & 0.120212 \\
\hline$W-172$ & $4.45 E-15$ & $3.20 E-14$ & 0.017928 \\
\hline W-173 & None Observable & $2.70 E-14$ & 0.000108 \\
\hline$W-174$ & $2.63 E-15$ & $4.44 \mathrm{E}-14$ & 0.010698 \\
\hline$W-175$ & $2.98 \bar{E}-15$ & $9.51 E-14$ & 0.0123 \\
\hline $\bar{W}-1 \overline{76}$ & $2.62 \mathrm{E}-15$ & $3.54 \mathrm{E}-14$ & 0.010622 \\
\hline W-177 & $6.20 \mathrm{E}-15$ & $2.69 \mathrm{E}-14$ & 0.024908 \\
\hline W-178 & $6.20 \mathrm{E}-15$ & $2.95 \mathrm{E}-14$ & 0.024918 \\
\hline $\mathrm{W}-179$ & $1.60 \mathrm{E}-13$ & $4.80 E-13$ & 0.64192 \\
\hline$W-180$ & $2.80 E-13$ & $6.90 E-13$ & 1.12276 \\
\hline$W-181$ & $1.30 E-13$ & $8.30 E-13$ & 0.52332 \\
\hline$W-182$ & None Observable & $1.85 \mathrm{E}-14$ & 0.000074 \\
\hline$W-183$ & $5.80 \mathrm{E}-15$ & $2.20 \mathrm{E}-14$ & 0.023288 \\
\hline$W-184$ & $2.70 E-15$ & $1.32 \mathrm{E}-15$ & 0.010805 \\
\hline$W-185$ & $1.30 \mathrm{E}-13$ & $2.60 \mathrm{E}-13$ & 0.52104 \\
\hline
\end{tabular}

It must be noted that the results of table 2 are not reflective of any actual internal exposures at WRAP. Using the maximum observed concentration at a location is an extremely conservative approach to access the criteria of 8 DAC-hr in a working shift.

\section{Potential for 4 DAC-hr Unplanned Increase in a Working Shift}

The accidents scenarios from the WRAP SAR were used to determine if a 4 DAC-hr unplanned increase in a working shift.

All of the accident scenarios involved waste containers or gloveboxes as the source of the radioactivity. The bounding consequence was $6.2 \mathrm{E}+01$ rem Effective Dose Equivalent (EDE) and a nominal consequence of $1.3 \mathrm{E}+01$ rem EDE for the Design Basis Earthquake, Table 3-30 Dose Consequences and Evaluation Guidelines for a Design Basis Earthquake (SAR). This is at a receptor location of 100 meters from the facility. This receptor is an individual that is in the path of the radioactive plume without any mitigation. Workers in the actual accident area (inside of WRAP) would terminate work activities immediately upon discovery, and evacuate the affected area. Estimated doses of up to one rem are mentioned in section 3.3.2.3.3 Worker Safety of the SAR for a 17 three types of accidents (mechanical breach. fire, fire/explosion). To determine the potential consequences from the various accident scenarios, the six bounding radiological accidents (nominal consequences) were calculated from the SAR. This is a 
"bounding" estimate of maximum exposure potential from the accident. It is not intended to estimate an individual workers exposure from the accident. The results of those calculations on an annualized basis are presented below.

From Section 3.4.2.1 Mechanical Release From Container Handling Accident (SAR)

5.7 E-05 PE-Ci $\times 1.4 \mathrm{E}+08 \mathrm{mrem} / \mathrm{Ci} \times 1.00 / \mathrm{yr}=7980 \mathrm{mrem}$

From Section 3.4.2.2 Fire Resulting From Drum handing Accident (SAR)

3.6 E-03 PE-Ci $\times 1.4 \mathrm{E}+08 \mathrm{mrem} / \mathrm{Ci} \times 2 \mathrm{E}-03 / \mathrm{yr}=1008 \mathrm{mrem}$

From Section 3.4.2.3 Explosion Resulting From Container Handling Accident (SAR)

9.4 E-03 PE-Ci $\times 1.4$ E+08 mrem/Ci $\times 3$ E-03 $/ \mathrm{yr}=3948 \mathrm{mrem}$

From Section 3.4.2.4 Fire In Process Enclosure - Glovebox (SAR)

2.7 E-03 PE-Ci $\times 1.4 \mathrm{E}+08 \mathrm{mrem} / \mathrm{Ci} \times 2 \mathrm{E}-03 / \mathrm{yr}=756 \mathrm{mrem}$

From Section 3.4.2.5 Explosion in Process Enclosure - Glovebox (SAR)

8.4 E-03 PE-Ci $\times 1.4 \mathrm{E}+08 \mathrm{mrem} / \mathrm{Ci} \times 3 \mathrm{E}-03 / \mathrm{yr}=3528 \mathrm{mrem}$

From Section 3.4.2.8 Design-Basis Earthquake (SAR)

1.1 E-02 PE-Ci $\times 1.4$ E+08 mrem/Ci $\times 1$ E-03 $/ \mathrm{yr}=1540 \mathrm{mrem}$

The three operating areas of WRAP are bounded by these accidents. Those areas are, Shipping/Receiving Area Rm 101. NDE/NDA Area Rm 104, and the Process Area Rm 107. Those three areas previously met the potential to exceed $2 \%$ of an ALI based on air sample data. Since the criteria of a 4 DAC-hr exposure equates to 10 mrem of dose, these accidents are more than likely to produce that dose to a plant worker in the affected area. The statement in the.SAR of doses up to one rem seems reasonable. Therefore, these three area were waste containers are stored and process meet the 4 DAC-hr criteria for an un-planned release and require continuous air monitoring.

\section{Dual Enclosure}

The dual enclosure criterion was evaluated by determining the confinement of incoming waste containers and the containment of the glovebox enclosures (including coupling drums to the glovebox and decoupling activities). Where drums from the gloveboxes do not have a strong-tight $7 i d$ in place. the dual enclosure criterion is not met. 
HNF-SD-W026-TA-002

Revision 2

Page 31 of 41

The following table summarizes these criteria for the fifty-eight rooms/areas of the WRAP complex. The highlighted rooms/areas require WAM. 


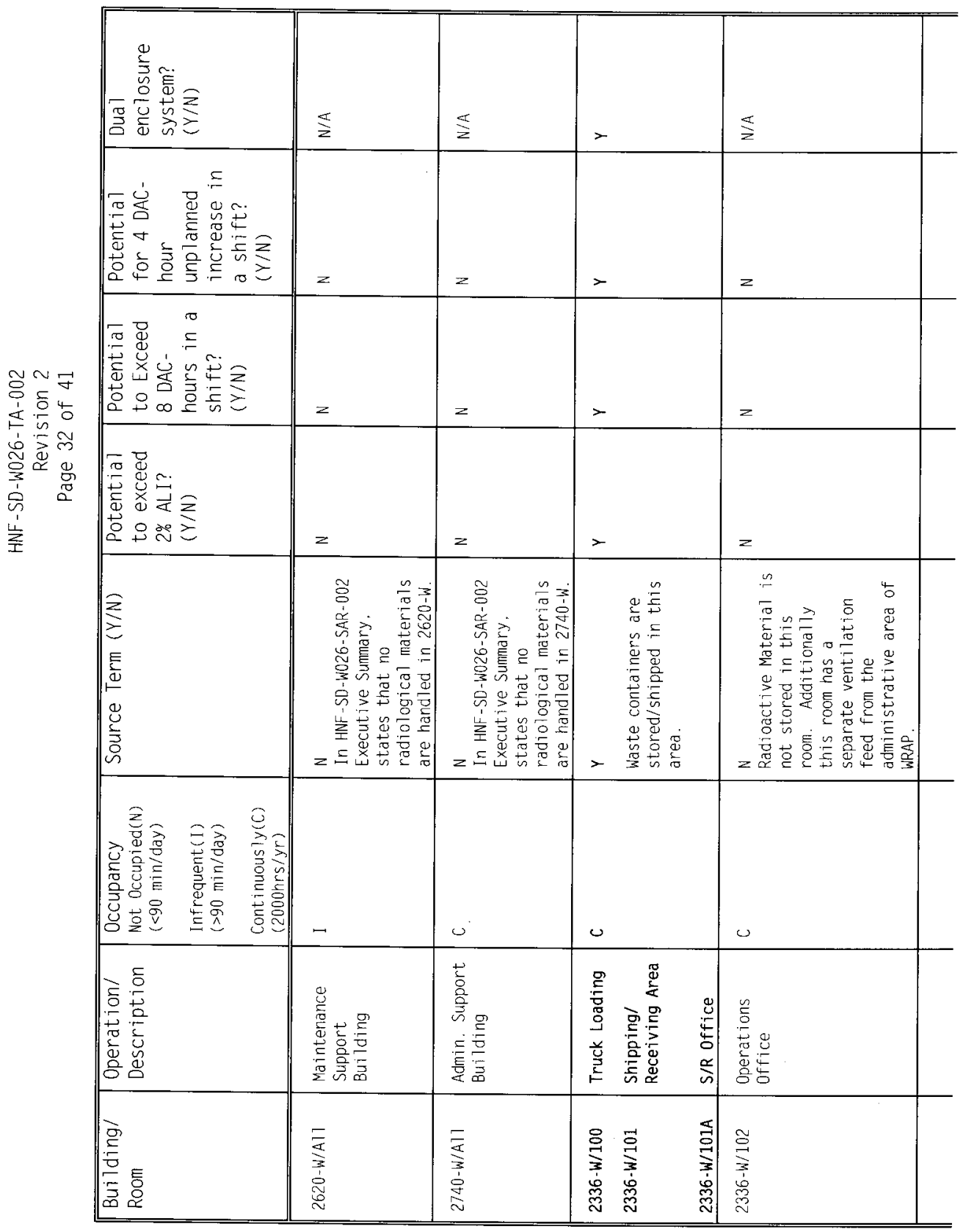




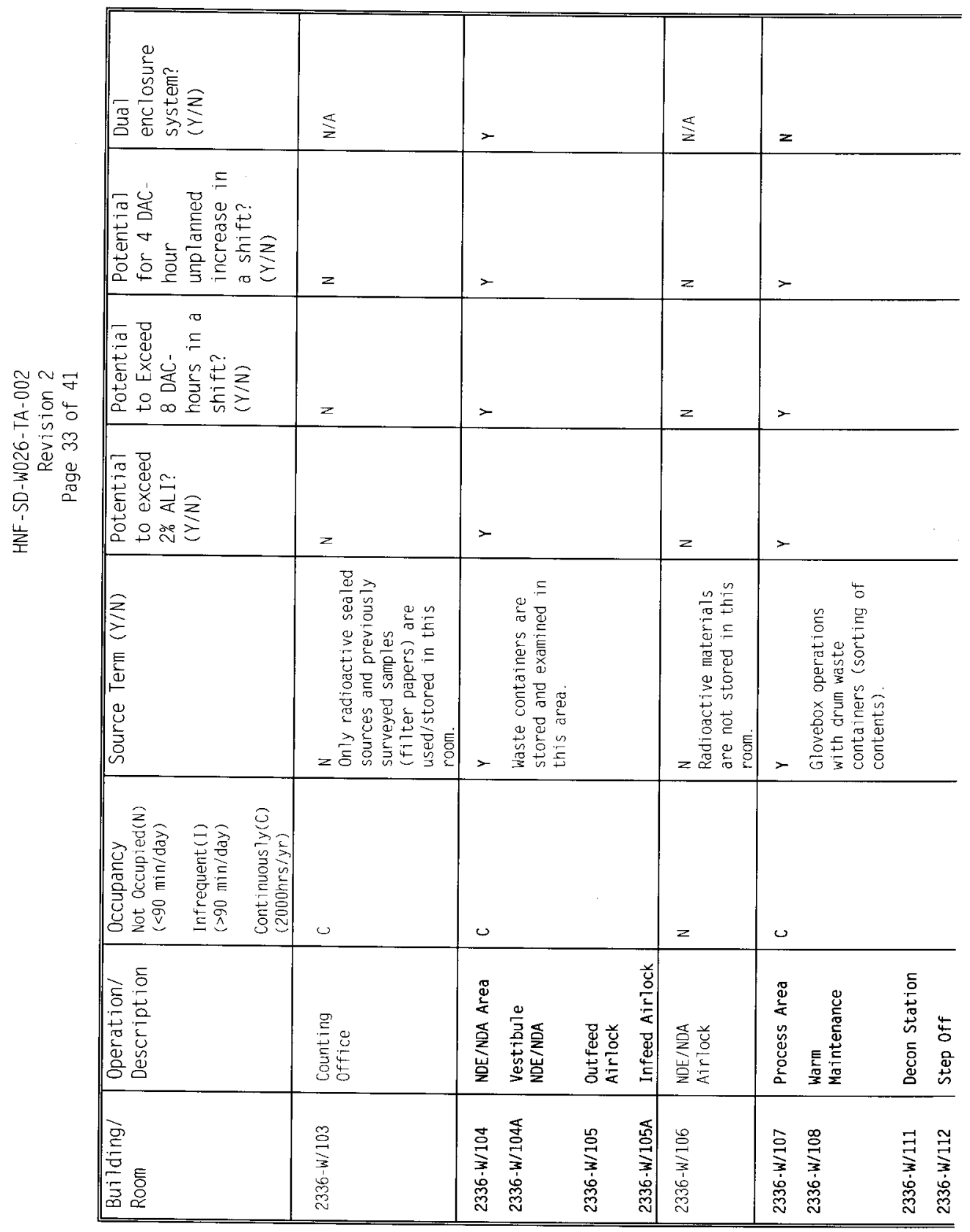




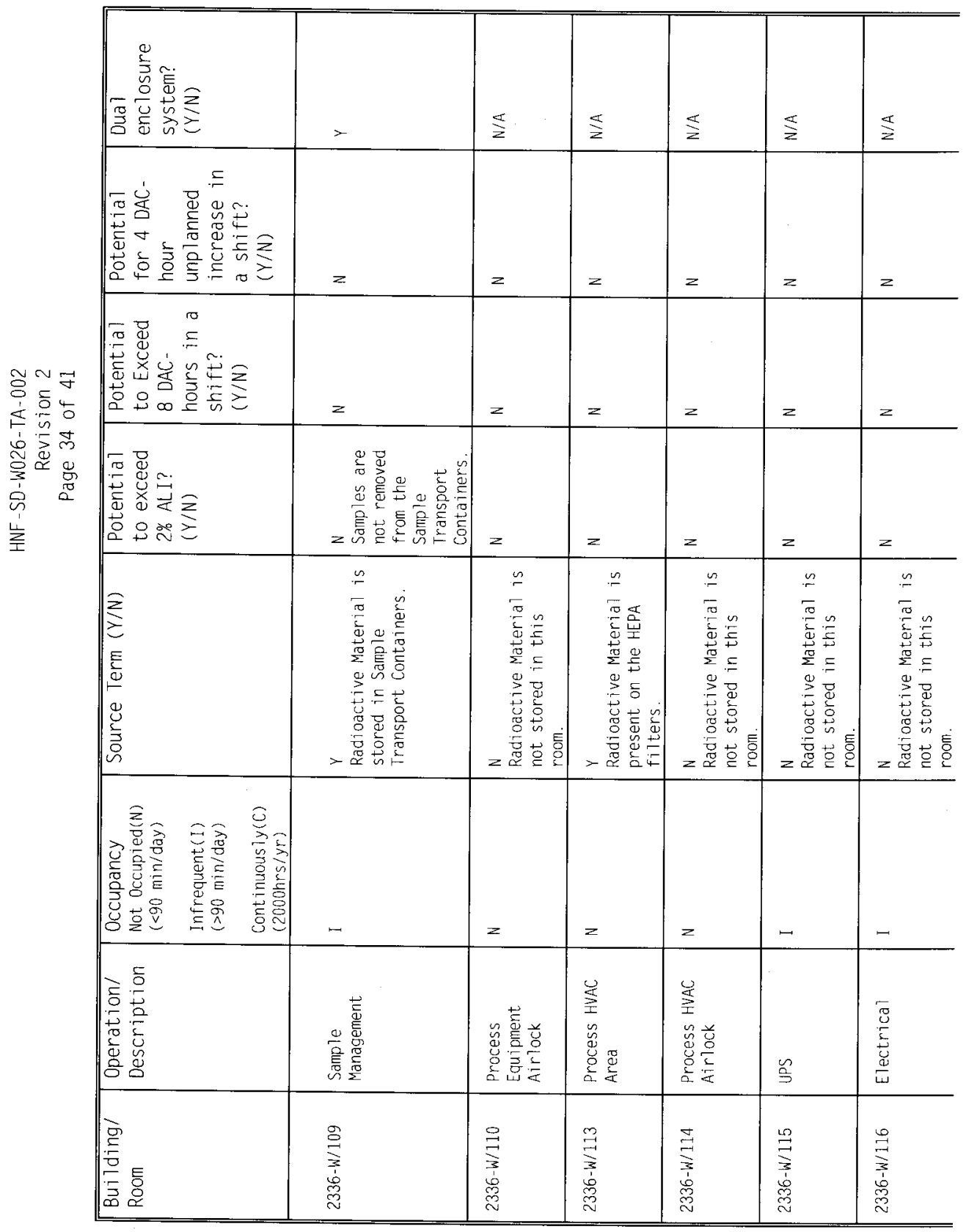




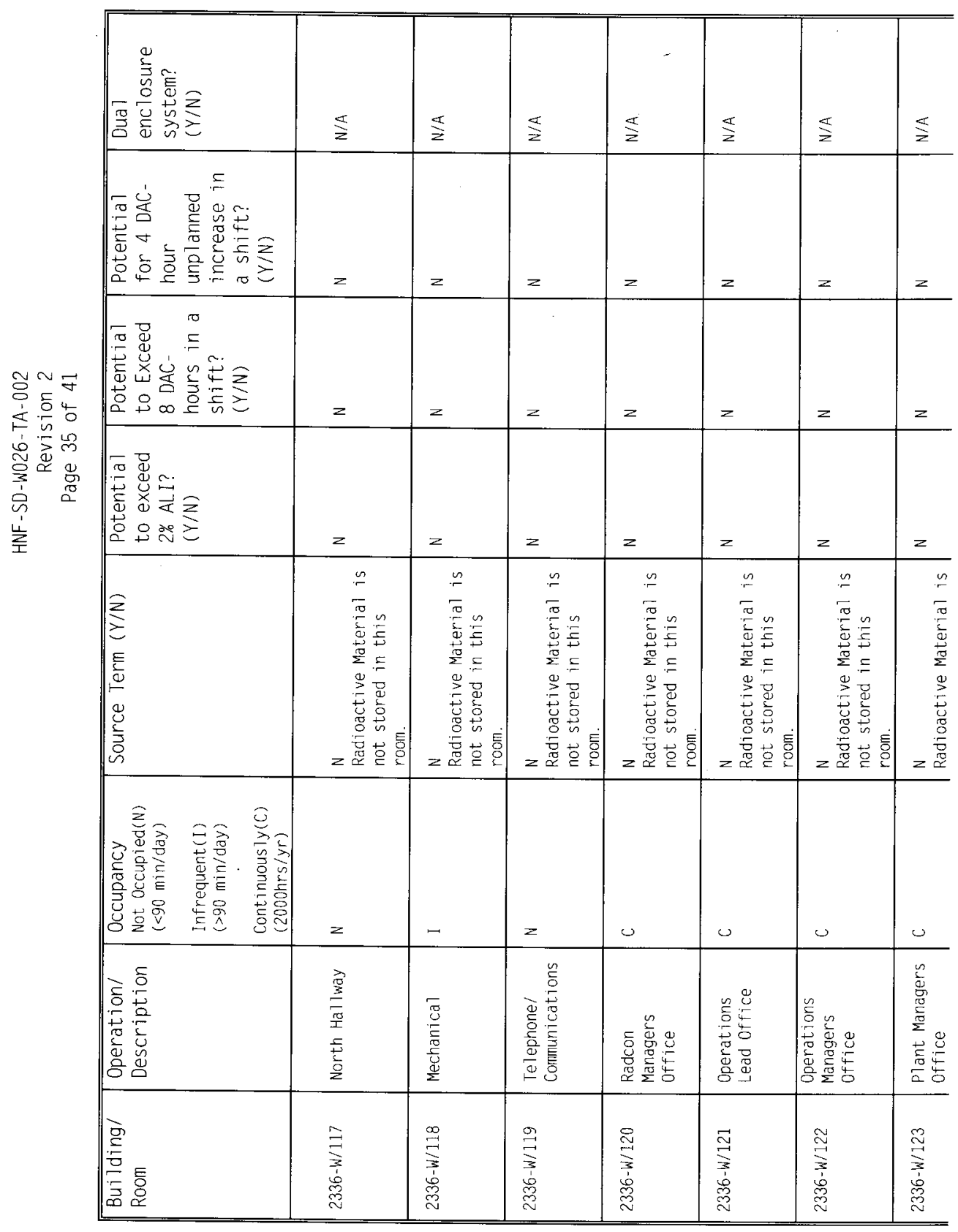




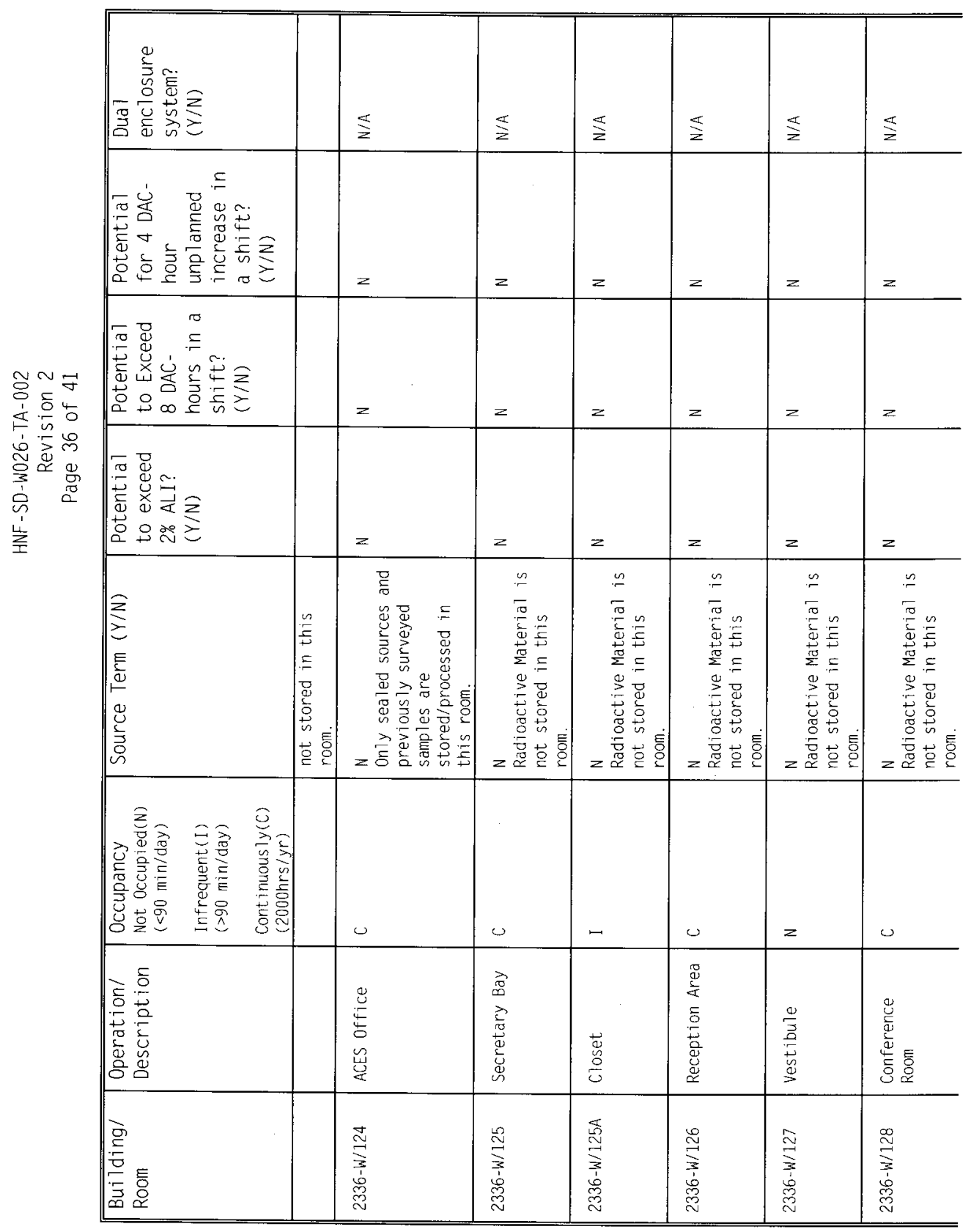




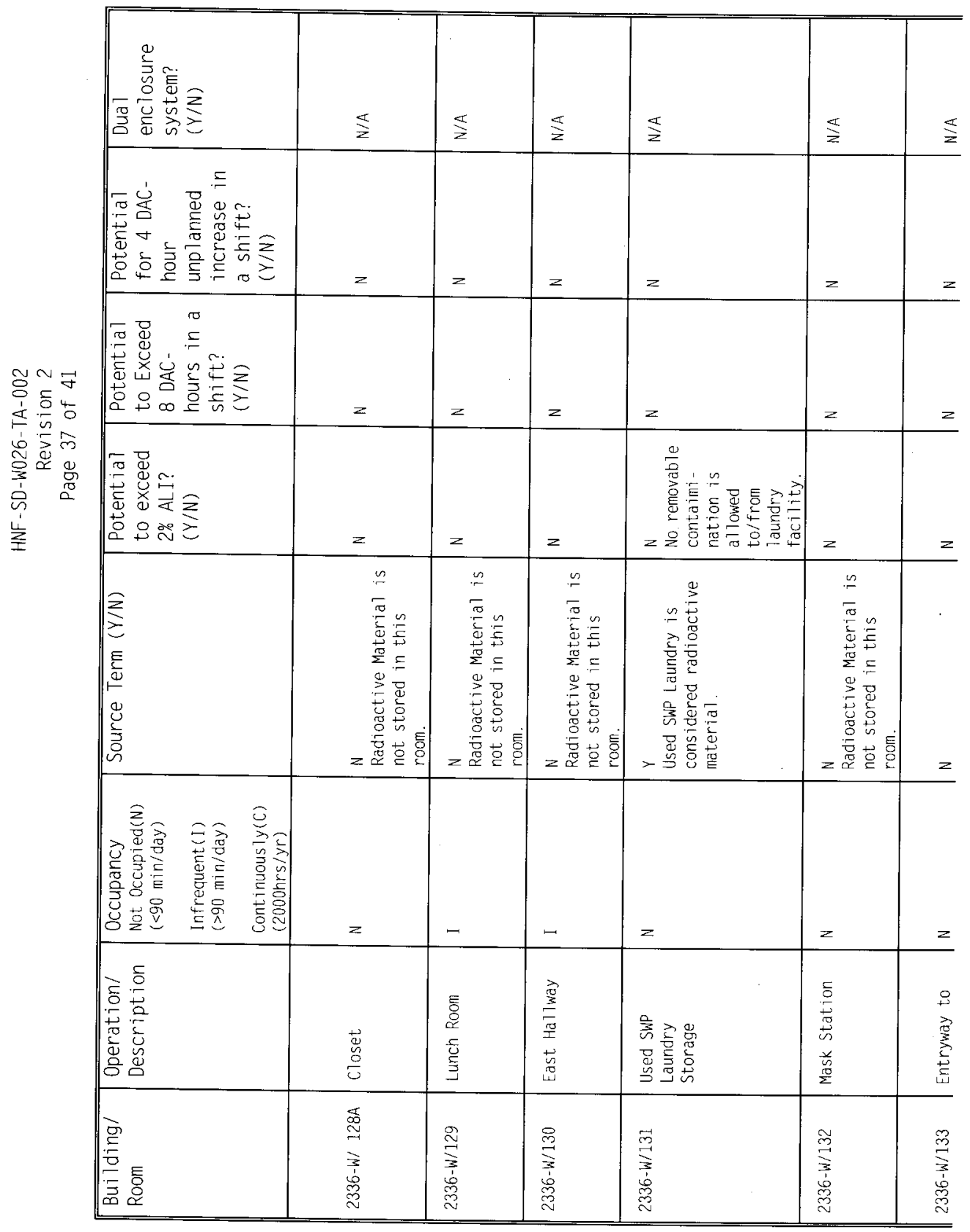




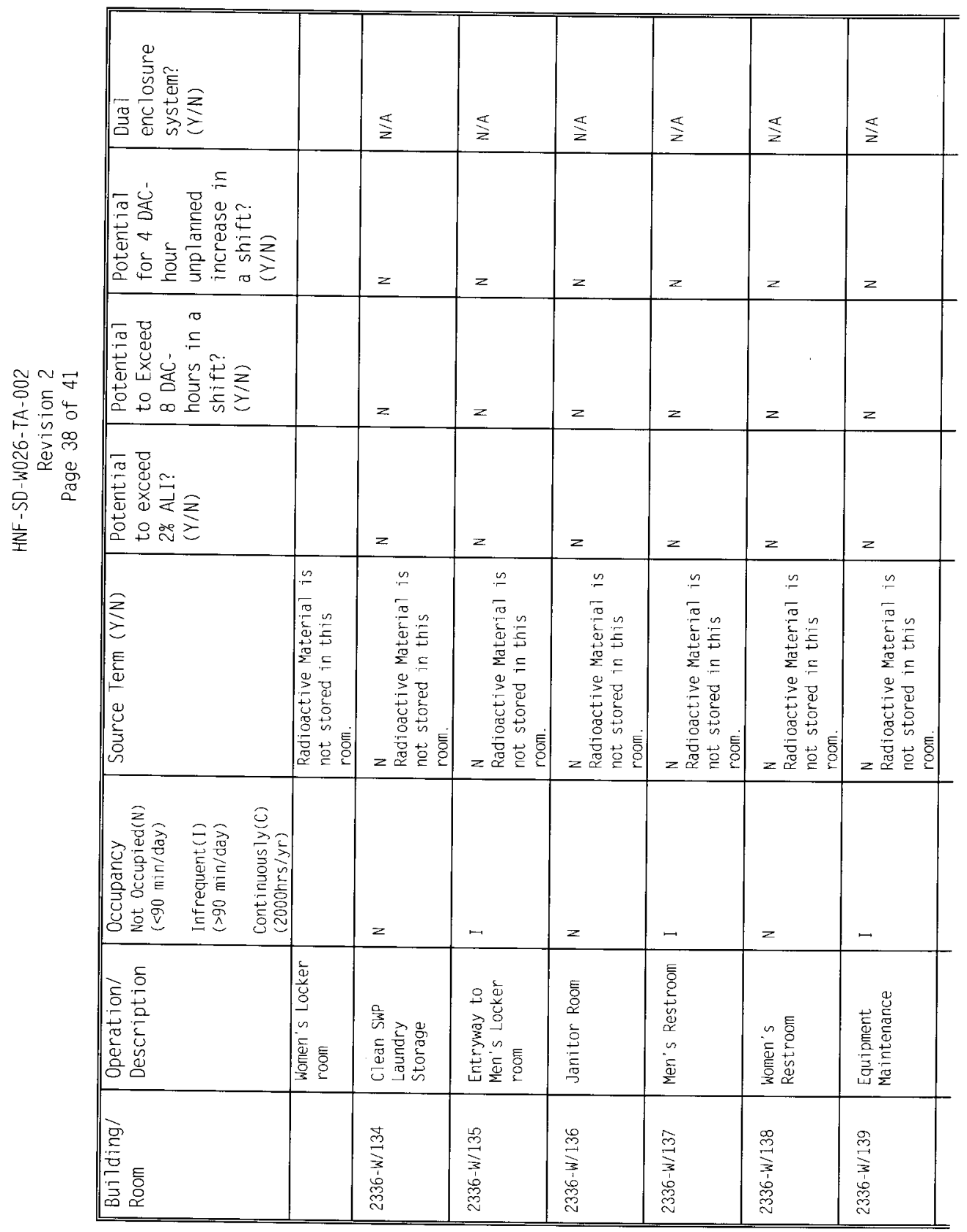




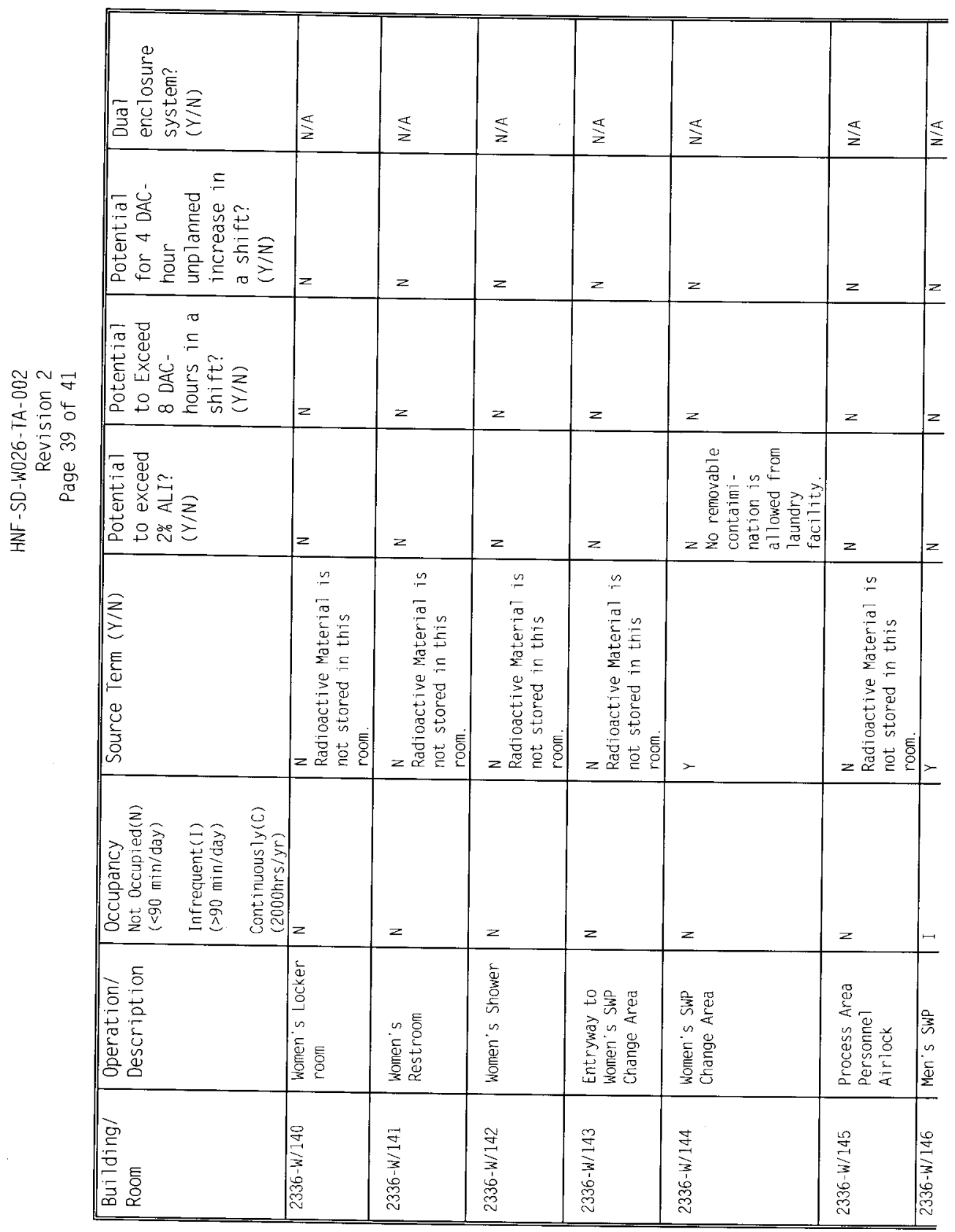




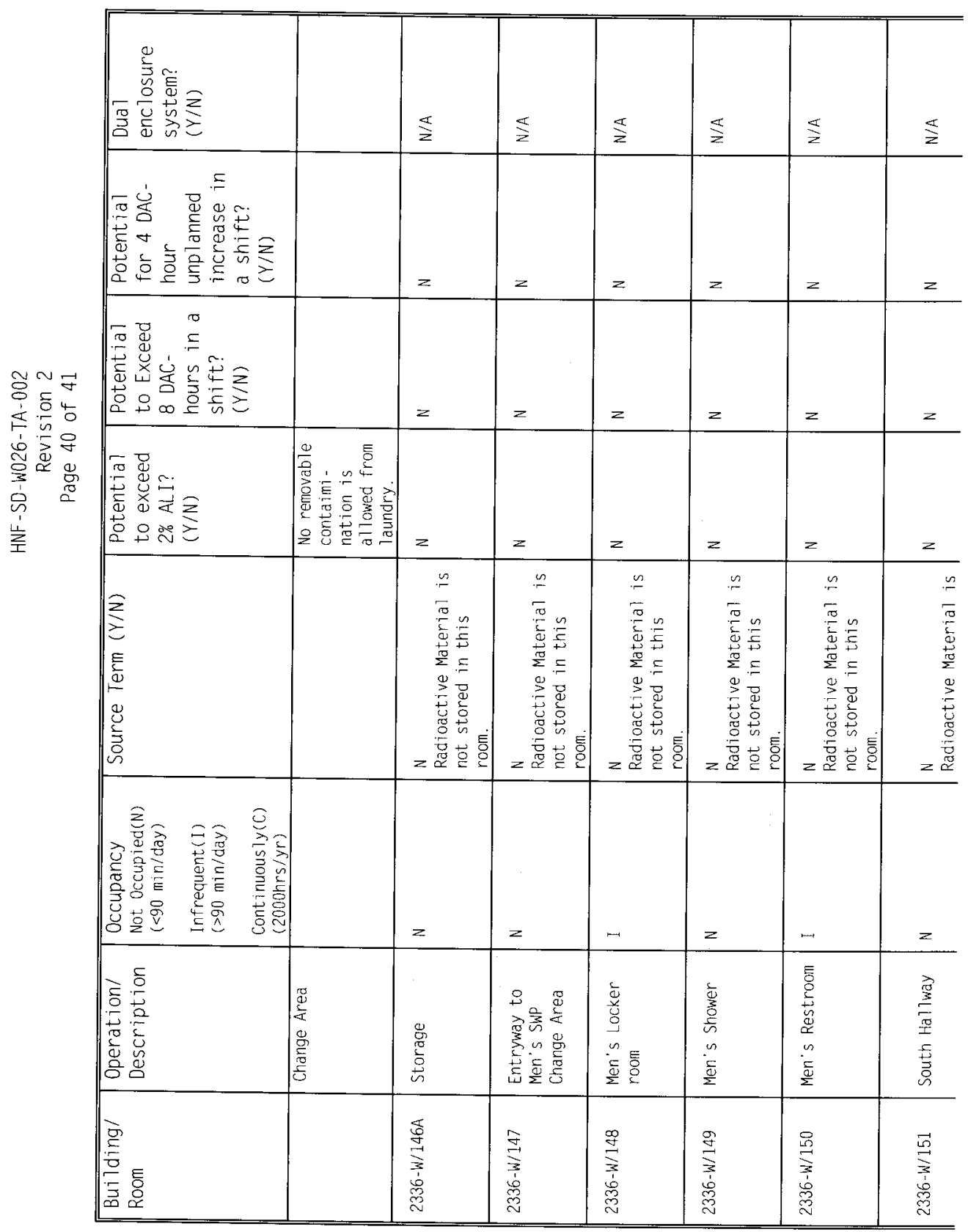




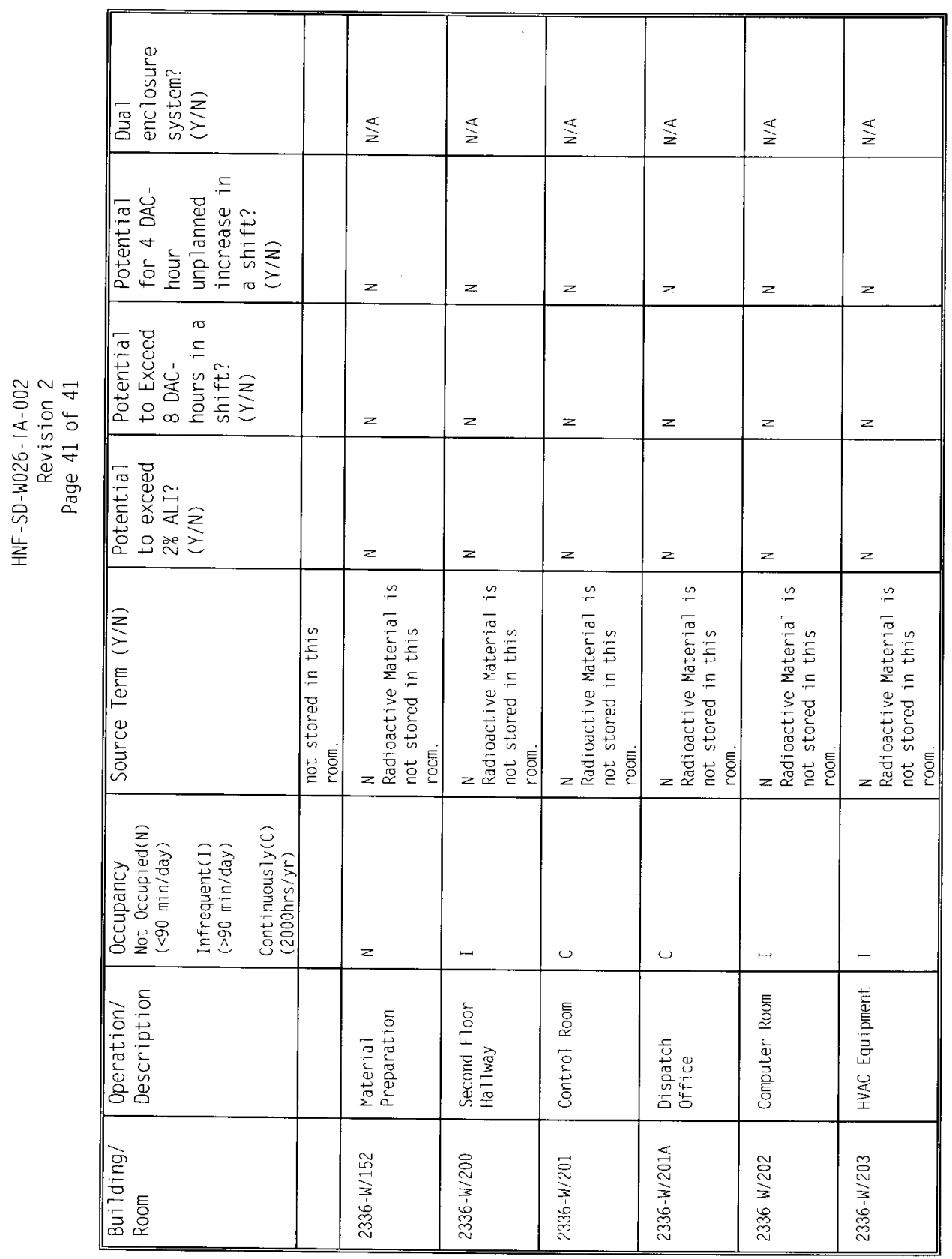




\section{DISTRIBUTION SHEET}

\begin{tabular}{|c|c|c|c|c|c|}
\hline \multirow{2}{*}{$\begin{array}{l}\text { To } \\
\text { Distribution }\end{array}$} & \multirow{2}{*}{\multicolumn{3}{|c|}{$\begin{array}{l}\text { From } \\
\text { WRAP Engineering }\end{array}$}} & \multicolumn{2}{|c|}{ Page 1 of 1} \\
\hline & & & & \multicolumn{2}{|c|}{ Date $02 / 08 / 99$} \\
\hline \multicolumn{4}{|l|}{ Project Title/Work Order } & \multicolumn{2}{|c|}{ EDT No. N/A } \\
\hline \multicolumn{4}{|c|}{$\begin{array}{l}\text { Technical Assessment of Compliance with Workplace Air Sampling } \\
\text { Requirements at WRAP }\end{array}$} & \multicolumn{2}{|c|}{ ECN No. ECN-651650 } \\
\hline Name & MSIN & $\begin{array}{l}\text { Text } \\
\text { With All } \\
\text { Attach. }\end{array}$ & Text Only & $\begin{array}{l}\text { Attach./ } \\
\text { Appendix } \\
\text { Only }\end{array}$ & $\begin{array}{l}\text { EDT/ECN } \\
\text { Only }\end{array}$ \\
\hline
\end{tabular}

MR Fishburn

T3-03 $X$

JC Givens

T4-52 X

MF Hackworth

T4-51 $X$

JK Kersten

T4-52 $X$

RJ Koll

T4-52 X

LW Roberts

T4-51

X

WR Thackaberry

T4-52

$x$

DN Stewart

T4-52 X

PK Hemsworth

T4-52

X

JR Weidert

T4-52

$x$

DOE/RL Reading Room

H2-53 X

Engineering Files

B1-07 $X$ 